Article

\title{
Reflection, Ritual, and Memory in the Late Roman Painted Hypogea at Sardis
}

\author{
Vanessa Rousseau \\ Independent Scholar, St. Paul, MN 55104, USA; rous0004@umn.edu \\ Received: 8 July 2019; Accepted: 14 August 2019; Published: 19 August 2019
}

\begin{abstract}
Wall painting in the Sardis hypogea expresses a regional visual language situated within the context of Late Antique approaches to decorative surfaces and multivalent motifs of indeterminate religious affiliation. Iconographic ambivalence and a typically Late Antique absence of illusionism creates a supranatural world that is grounded in the familiar imagery of home and gardens but does not quite reflect the natural world. Ubiquitous and mundane motifs were thus elevated and potentially charged with polysemic allusions to funerary practice and belief. Twelve fourth century C.E. hypogea form a distinctive corpus with a largely homogenous decorative program of scattered flowers, garlands, baskets, and birds. Related imagery is common throughout the larger Roman world, but compositional parallels from Western Anatolia suggest a particularly local visual vocabulary. The chronologically, geographically, and typologically discrete nature of the Sardis corpus set it apart from the standard of Rome while underscoring commonalities in late Roman funerary decoration and ritual. The painted imagery evoked funerary processes and ongoing social negotiation between the living and the deceased.
\end{abstract}

Keywords: Late Roman art; Late Antique art; wall painting; fresco; tombs; Sardis; funerary; archaeology; ritual

\section{Introduction}

This study considers how painted decoration in a set of twelve fourth century C.E. hypogea from Sardis reflects contemporary wall painting as well as funerary rituals used to negotiate loss and memory. The Sardis corpus has affinities with sepulchral painting found throughout the Roman empire, including the Roman catacombs, but comprises a distinct regional style with the closest parallels in Anatolia at sites like Ephesus. A few of Sardis' painted tombs have been preliminarily published in excavation reports or wall painting articles, but this is the first synthetic publication of the corpus. This article seeks to situate the painting programs within the context of regional painting and also within the broader scope of Late Antique funerary practice during this era of artistic and religious transition. This discrete group of paintings augments the existing body of Roman wall painting and reinforces what is understood about the syncretistic nature of Late Antique art and culture while demonstrating some local and chronological idiosyncrasies.

The Sardis hypogea (Figure 1) raise questions about the relationship between domestic and funerary painting and the motives behind the decorative motifs. As represented at Sardis, tomb decoration had become schematized into its most basic elements, with simplified forms and the lack of concern for spatial logic typical of Late Antique decoration as well as earlier non-elite Roman funerary art. The elements from the Sardian program of freefield scattered flowers, garlands, baskets, and birds are typical of semantically ambivalent decorative motifs in Late Antiquity that make it challenging to ascribe meaning, or intent, to non-narrative imagery. Painting choices among these tombs underscore ideas about the relationship between domestic and sepulchral painting, the tomb as a ritual and memorial space, and interaction and evocation as a component of decorative choice. I begin with an overview of the hypogea and their typical 
painting program, followed by the exceptions that underscore the common imagery. This is followed by a discussion placing the painting in context among wall painting comparanda, funerary ritual, and Late Antique iconographic and stylistic attitudes. A final Appendix outlines the details for each tomb.

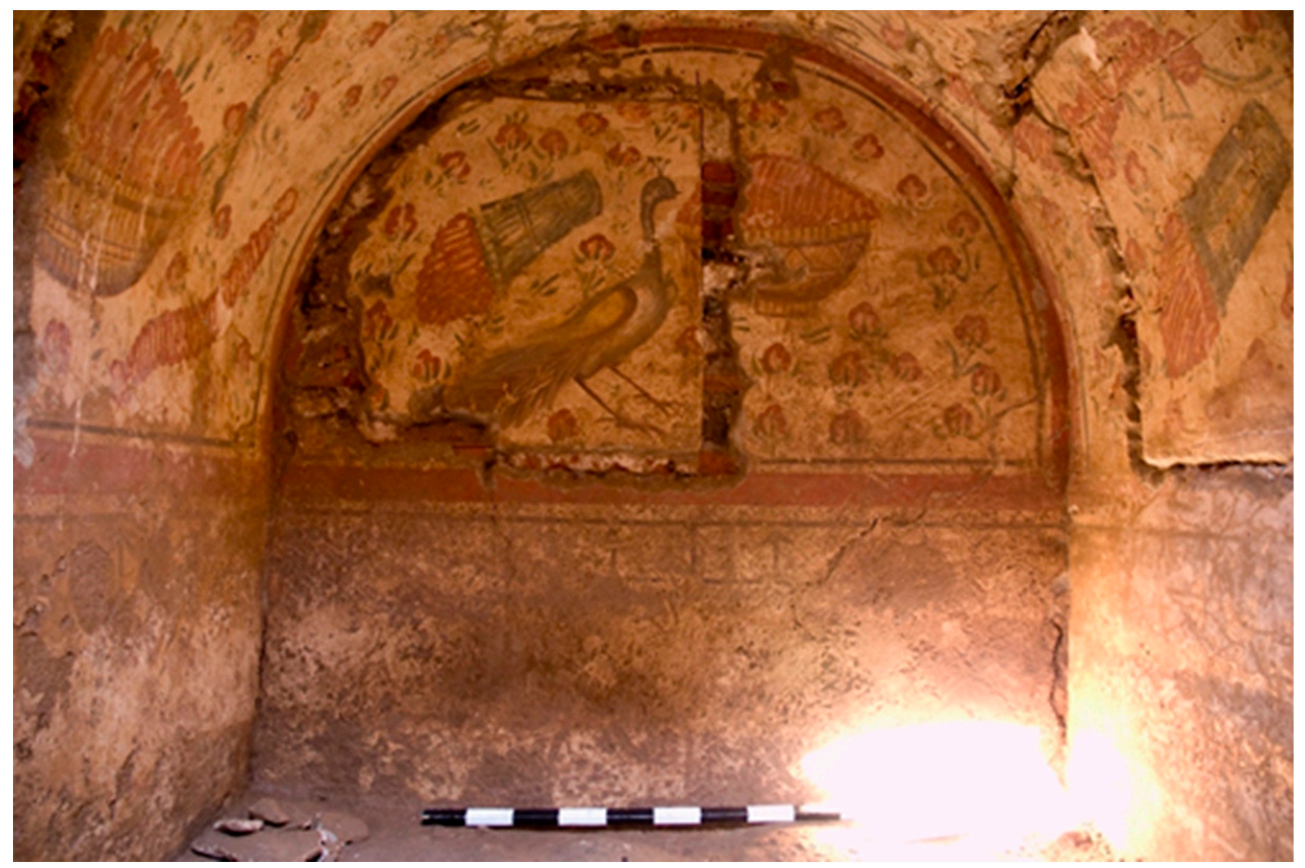

Figure 1. Sardis, Tomb 07.3 (Appendix A.5), west wall. (C) Archaeological Exploration of Sardis/President and fellows of Harvard College.

\section{Roman Sardis and the Painted Hypogea}

As part of Diocletian's reorganization of the empire in 296 C.E., Sardis became the capital of the new Roman province of Lydia in Asia Minor. ${ }^{1}$ This prosperous era included major commercial, residential, and religious building projects continuing into the fourth and fifth centuries (Hanfmann and Mierse 1983, p. 146; Hanfmann and Waldbaum 1975, pp. 32, 191). These included an extension of the city wall c. 350-400 that may have incorporated part of a former burial precinct. ${ }^{2}$ Most of the known hypogea are in the area stretching north from the Artemis temple to the Izmir-Ankara highway between the slopes of the acropolis and the Pactolus River in an area that was originally outside of the city wall (Figure 2). All of the painted hypogea discussed here have been accidental discoveries, and the full extent of Sardis' cemeteries is still revealing itself. ${ }^{3}$ Some of the hypogea were built on top of pre-existing graves, suggesting a formal cemetery precinct used and reused over generations, probably by various economic classes. The painted hypogea appear for a discrete period of time, mixed with other burial types, representing a local elite fashion during the mid-late fourth century C.E. The fact that hypogea seem to be in cemetery precincts but are relatively scarce suggests that they expressed high status, but probably not any particular religious belief. Jewish and Christian communities prospered at Sardis at this time, but the graves reveal little indication of religious affiliation or separation according to

1 The site of Sardis in Western Anatolia was historically important from the Lydian through the Late Roman and Byzantine periods, and the history and population of Sardis reflected the multicultural quality of the Roman empire. The Harvard-Cornell Archaeological Exploration of Sardis has exposed remains of public and private buildings and tombs from all eras of occupation.

2 For a discussion of dating the phases of the city wall, see (Rautman 2011, pp. 11-12).

3 A number of cemeteries have been identified along with reuse or repurposing of sites within the city. For an overview of these areas, see (Hanfmann and Mierse 1983, pp. 204-10). 
religious beliefs. ${ }^{4}$ Instead, decorative choices were related much more to funeral ritual and ongoing social negotiation than to belief systems.

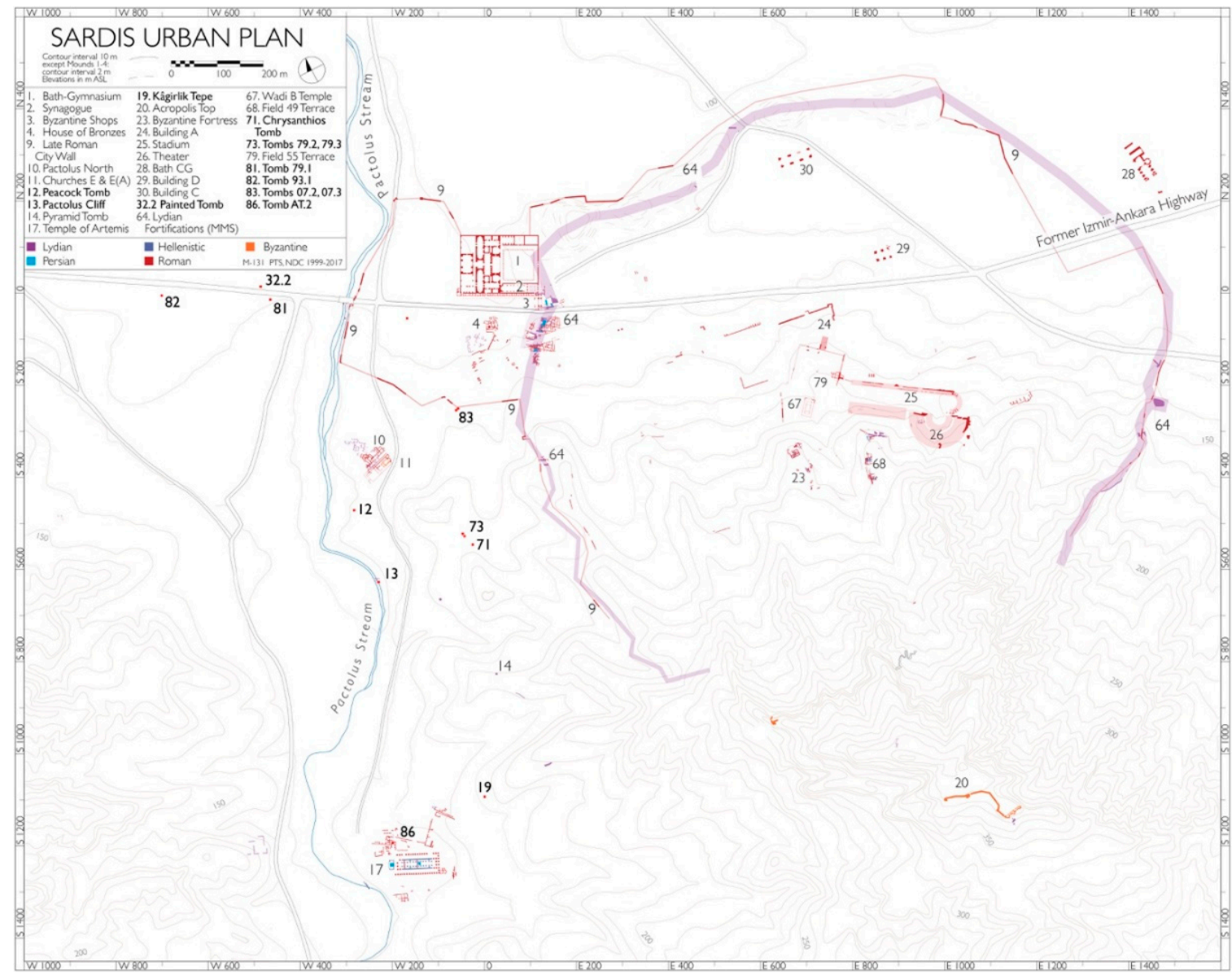

Figure 2. Sardis Urban Plan with hypogea locations indicated in bold. (C) Archaeological Exploration of Sardis/President and fellows of Harvard College.

\section{Standard Decorative Program and Technique}

The regularity of the Sardis hypogea suggests a common workshop active for a discrete period of time that perhaps represents an elite funerary fashion. ${ }^{5}$ No two are precisely identical, but they share construction techniques and a consistent painting style and palette. The rectangular, barrel-vaulted tombs are roughly $3 \mathrm{~m}$ long by $2.5 \mathrm{~m}$ wide and $2 \mathrm{~m}$ tall, equipped with built-in steps and a removable slab covering the entrance hole in the vault (Figure 3). It seems likely that stelae or mounds marked the graves in antiquity, but no evidence of this remains.

4 This is, admittedly, difficult to quantify in the absence of much archaeological or epigraphic evidence indicating religious belief, but Johnson makes it clear that burial was more commonly based on kinship or collegial ties (Johnson 1999, pp. 402-6). Similarly, Noy and Williams both demonstrated that Jewish burials in Rome were interspersed with those from other faiths and in general influenced more by broader Roman culture than a governing Jewish body or process (Noy 2004; Williams 1994, pp. 179-82), and Cormack notes that the funerary inscriptions of Roman Asia Minor, while revealing social status, etcetera, rarely reveal religious beliefs or hopes for the afterlife (Cormack 1997, p. 151).

5 For patterns or model books, see (Scheller 1995; Schmidt-Colinet 1996). 


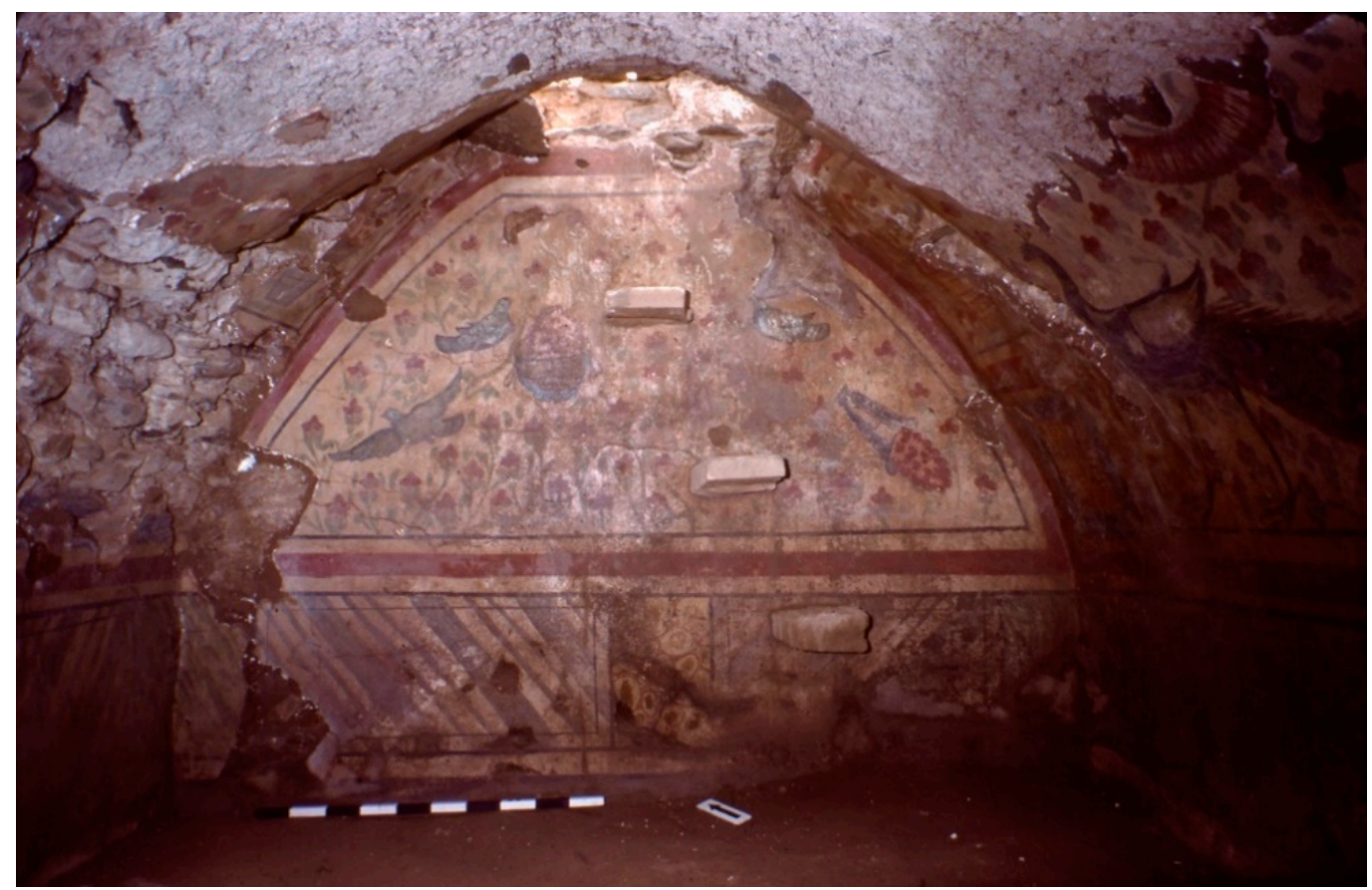

Figure 3. Sardis, Tomb of Chrysanthios (Tomb 76.1, Appendix A.1), north wall with offset cantilevered steps and vault entrance above. (C) Archaeological Exploration of Sardis/President and fellows of Harvard College.

The hypogea interiors were painted quickly with a minimum of brushstrokes, primarily on a dry (a secco) surface, occasionally with inscribed guidelines. In some areas, the colors blend with the white plaster as in buon fresco, but this painting on wet plaster was likely a matter of happenstance. ${ }^{6}$ The decorative programs share the same basic composition and repertoire of motifs and framing devices: Broad bands of dark red paint frame the walls, dividing a lower dado course from a taller field above. ${ }^{7}$ Where the dado course survives, it has one of two patterns: a rinceau and arrow or candelabra pattern (Figures 1, 13, 14, A3 and A4), or simulated marble (Figure 3). ${ }^{8}$ The upper zone was then filled with freefield scattered red flowers and worm-like accordion-style garlands, the occasional wreath, and baskets of perhaps fruit or flowers. Birds perch, fly, and peck in various states of naturalism (Figure 4). Aside from peacocks, few are clearly identifiable with specific species. ${ }^{9}$ An absence of compositional naturalism distinguishes the ephemeral "freefield" pattern of scattered flowers from other floral painting that mimics a view potentially found in nature such as the many painted gardens on domestic Roman walls or the hypogeum of the Octavii in Rome. ${ }^{10}$ Instead, painters have used simple forms to capture the effect of scattered flowers.

6 The pigments, not soluble in water, probably had lime plaster as a binding medium mixed with pigment and applied to a wetted wall. The pigments used include lime white, carbon black, light and dark red earth, yellow ochre, umbers, green earth, and granular Egyptian blue (Majewski 1970, p. 55).

7 Red framing of edges and dado zone are common in tombs elsewhere, including those from the upper city necropolis at Ephesus dated from the second-early fourth centuries (Zimmermann et al. 2011, pp. 143-46).

8 I have only found dado-level trident, candelabra or rinceaux designs in tombs at Sardis, but they are not uncommon in domestic settings of the Roman east from the first c. B.C.E. to the fourth century. Alix Barbet compiled examples from a number of Roman sites that nicely illustrate the evolution of the candelabra-type volute into a more geometric trident (Barbet 2005, p. 201, Figure 113). See also examples from Masada (Rozenberg 1996) and Corinth (Gadbery 1993, p. 55).

9 A few have longish tails suggesting peahens, natural partners for the peacocks nearby. The other, more compact and rounder, birds are probably doves or pigeons. The birds in Terrace House 2 at Ephesus include invented varieties (Zimmermann et al. 2011, pp. 133-35).

10 On the Via Triumphalis (Borg 2013, Figure 40). 


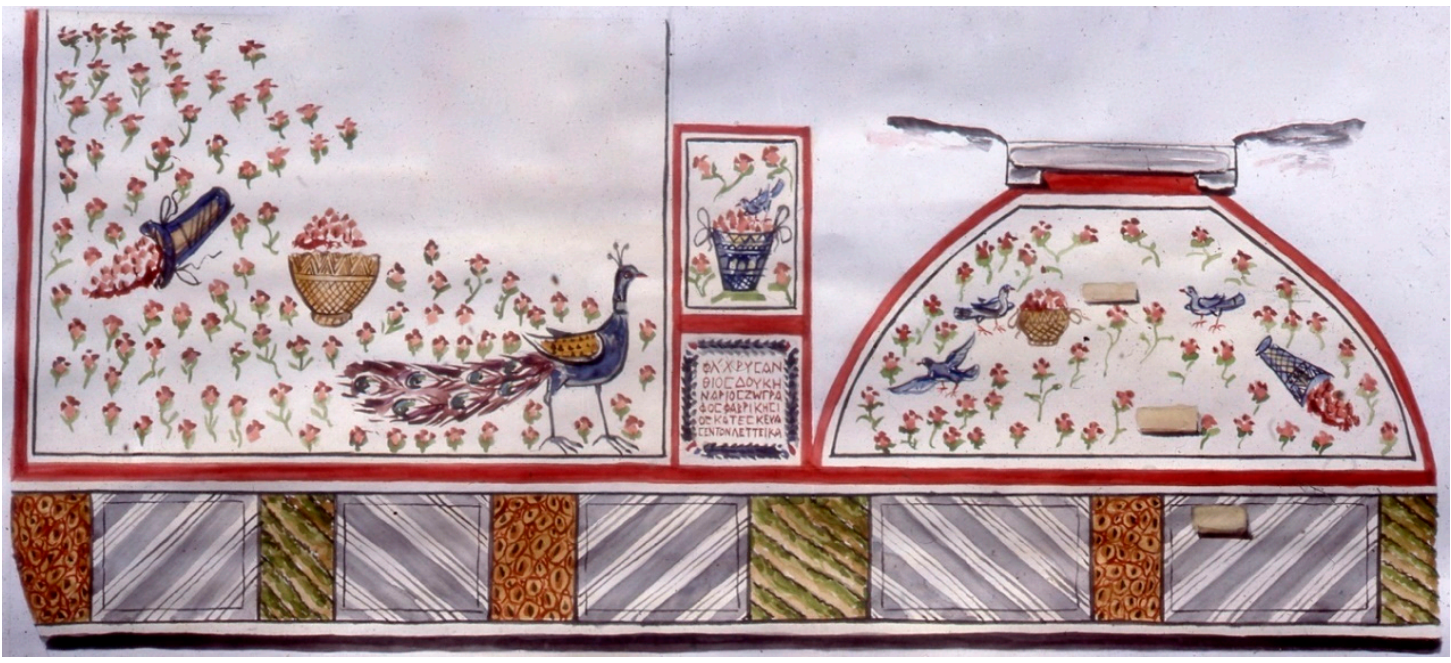

Figure 4. Sardis, Tomb of Chrysanthios (Tomb 76.1, Appendix A.1), painting of west and north walls. (C) Archaeological Exploration of Sardis/President and fellows of Harvard College.

\section{Exceptional Tombs and Chronology}

A few of the Sardis tombs include unique personalizations or stylistic differences but are otherwise in keeping with the standard painting program. These exceptions are intriguing for their variation and choices but also highlight what is consistent in the decorative program. Likewise, the stylistic and compositional uniformity of the hypogea supports a narrow period of construction and decoration, very likely by a single workshop. Therefore, elements that date one tomb may be largely applied to the balance of the corpus. Despite a paucity of datable grave goods, archaeological, paleographic, and art historical correspondences indicate fourth century dates for most of the Sardis hypogea.

The most compelling evidence for dating comes from the most highly decorated of these tombs: The "Tomb of Chrysanthios" (Figures 4-7) The decorative program includes the usual dado with simulated marble surmounted by a freefield composition of peacocks, doves, baskets, wreaths, and scattered flowers in panels framed by thin black and broad red bands. In addition, there were three wreathed inscriptions on the west, east, and south walls and fragments of a fourth in the center of the vault. ${ }^{11}$ The south lunette inscription and inscriptions in the square wreaths on the north ends of the east and west walls, respectively, read:

God (the boethei) give help to Fl[avios] Chrysanthios, doukenarios fabrikesios, (who) for himself and his family built this tomb with his wife and children

Fl[avios] Chrysanthios built this tomb

Fl[avios] Chrysanthios doukenarios zographos fabrikesios built this tomb

The epithet doukenarios fabrikesios records Chrysanthios' identity as a salaried high official and armorer, presumably in the arms factory, or fabrica, established at Sardis in the time of Diocletian or Constantine I (no earlier than 280 C.E.) (Greenewalt 1978, p. 61). The painted inscriptions set this tomb apart, not only for providing a glimpse of the deceased, but also for dating and style. Though the forms are simple, the inscribed wreaths were painted with greater care than the other wreaths, flowers, and perhaps even birds (Figure 6). The epithet zographos, or "painter from life", from the west wall presents the possibility that Chrysanthios himself may have painted the inscriptions. Greenewalt suggested that Chrysanthios was an amateur painter, noting that the low status of a professional painter would have been in conflict with his position as doukenarios fabrikesios, fitting him instead into the long tradition

11 Only a few letters survived from the vault (Greenewalt 1979, p. 5). 
of dilettante artists among the Roman upper classes (Greenewalt 1979, pp. 5-6, n. 9). ${ }^{12}$ Hanfmann (1981, p. 88), however, argued that Chrysanthios may have been employed in the fabrica as a painter of parade armor, such as the shields made of plastered and painted wood found at Dura Europos. Either option leaves open the intriguing possibility that Chrysanthios himself painted some parts of the tomb.

The wreathed invocation from the south wall, "the boethei" (God), suggests that Chrysanthios was Christian, as this invocation appears in Christian, but not pre-Christian, epitaphs (Greenewalt 1979, p. 8, n. 10). Chrysanthios' use of Constantine I's praenomen Flavios further suggests a religious affinity with Constantine and a post-313 C.E. date (Hanfmann and Mierse 1983, p. 208; Foss 1976, p. 281). This epigraphic evidence thus sets a date range c. 280-400.

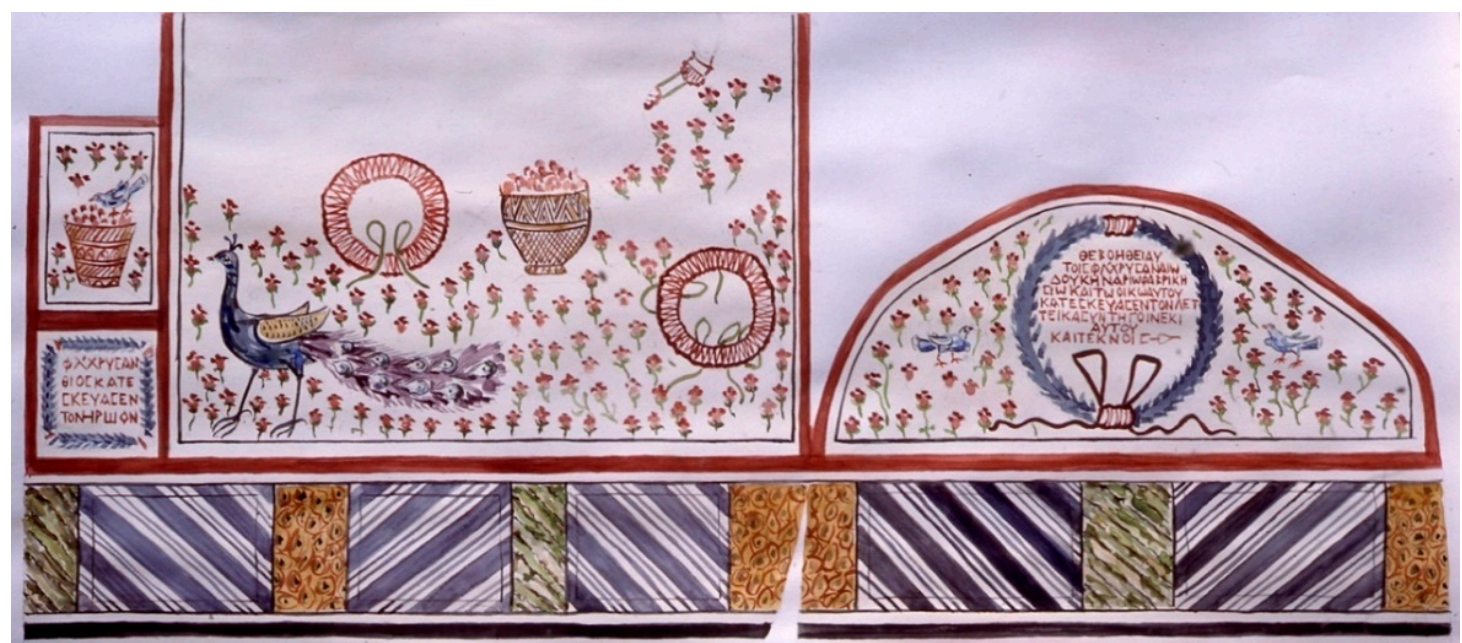

Figure 5. Sardis, Tomb of Chrysanthios (Tomb 76.1, Appendix A.1), painting of east and south walls. (C) Archaeological Exploration of Sardis/President and fellows of Harvard College.

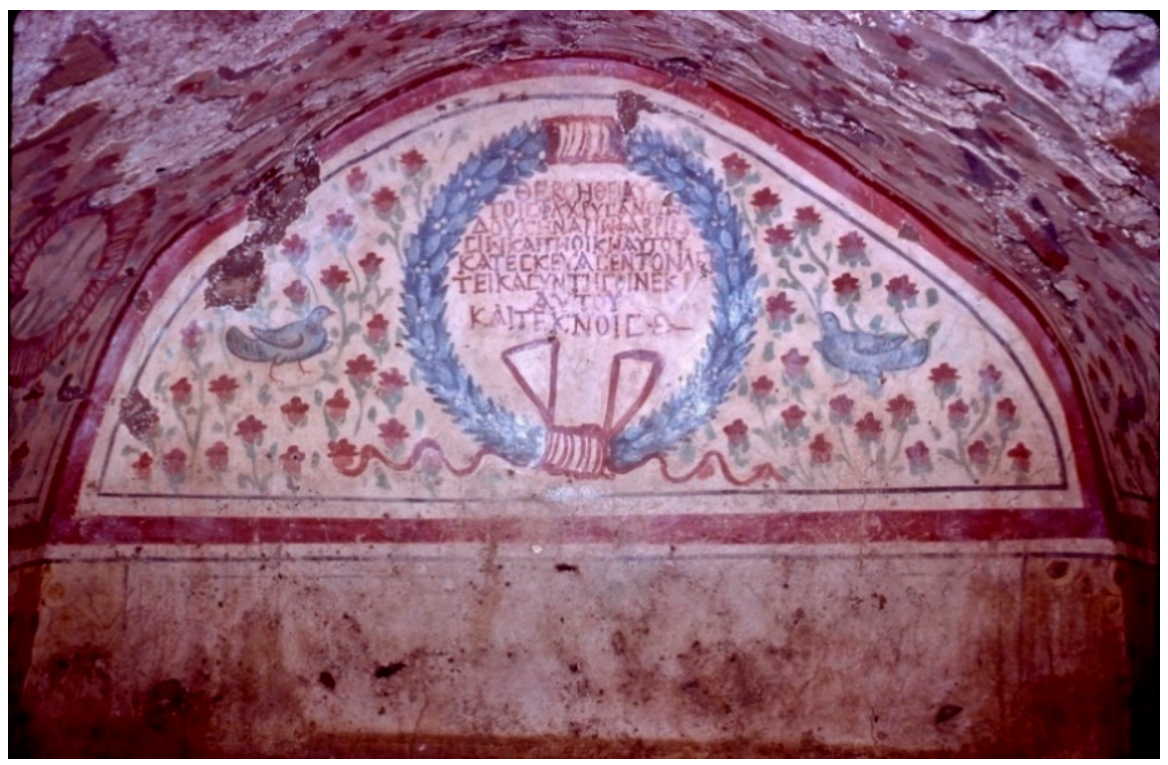

Figure 6. Sardis, Tomb of Chrysanthios (Tomb 76.1, Appendix A.1), south wall. (C) Archaeological Exploration of Sardis/President and fellows of Harvard College.

12 Hemans pointed out that the Chrysanthios tomb shows a familiarity with current styles and techniques, and (assuming that the deceased did at least some of the painting here) suggests that Chrysanthios had painted on plaster before (Hemans 1987, p. 164). See also (Foss 1979). 


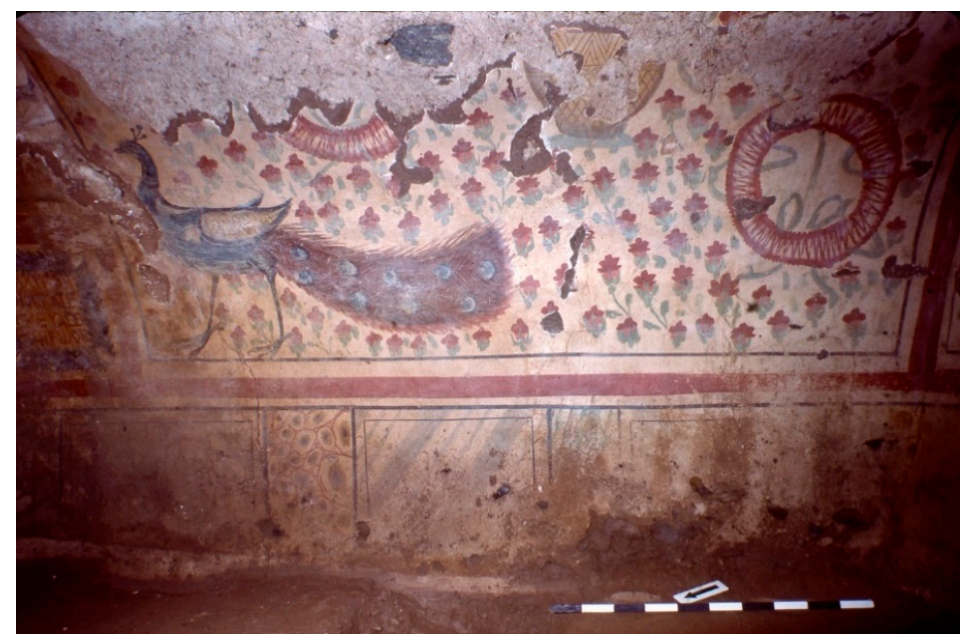

Figure 7. Sardis, Tomb of Chrysanthios (Tomb 76.1, Appendix A.1), east wall. @ Archaeological Exploration of Sardis/President and fellows of Harvard College.

The only other tomb with an inscription, the "Painted Tomb" (Figures 8-11), makes the religious beliefs of the deceased clear via a Constantinian Chi-Rho. This inscription also offers the only unequivocal evidence of belief systems in the Sardis hypogea. The west wall lunette features a wreath with trailing ribbons that encloses the Chi-Rho monogram flanked by Alpha and Omega. ${ }^{13}$ The Christogram is rare in Late Antique paintings, but when datable, is rarely earlier than the mid-fourth century. ${ }^{14}$ The open Rho is characteristic of eastern examples of salutare signum and the square Omega is common in third and fourth century inscriptions, supporting a fourth century date for the tomb. ${ }^{15}$

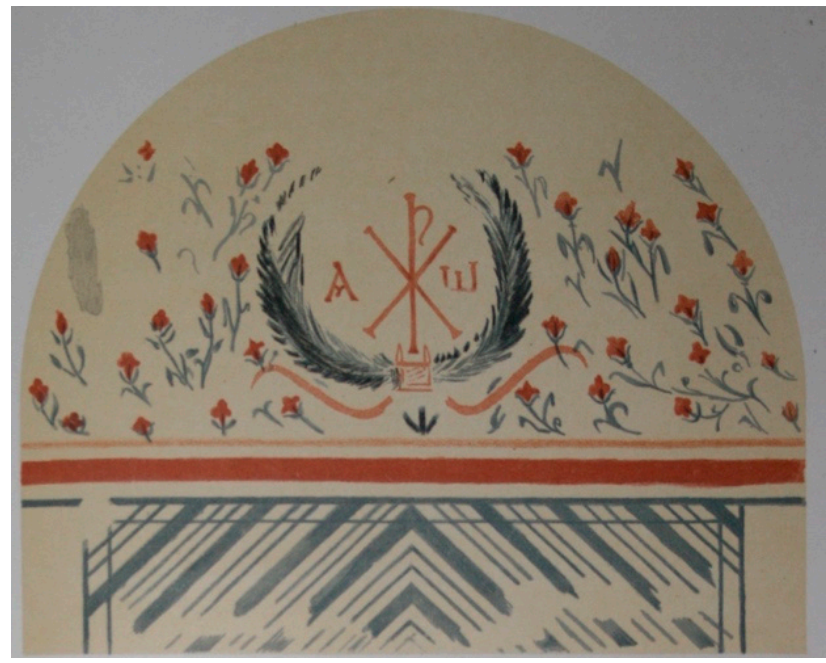

Figure 8. Sardis, "Painted Tomb" (Appendix A.2 T2), painting of west wall. (C) Archaeological Exploration of Sardis/President and fellows of Harvard College.

13 In addition to functioning as perpetual offerings to the deceased, wreaths were also pre-Christian symbols of special status later associated with immortality and then eternal life in the Christian context. For example, St. Paul speaks of the "imperishable wreath" granted to baptized Christians who succeed to eternal life. I Corinthians 9: 24-27. Goodenough describes the wreath as enclosing and thus protecting and sanctifying objects for pagans and probably for Jews and Christians as well (Goodenough 1965, pp. 42, 62). See also Pencheva on the wreath as indicator of ritual or change in status in Hellenistic Thrace (Pencheva 2017).

14 A notable exception is the Iznik Tomb, dated to the first third of the fourth century (Barbet 2007, p. 138).

15 Morey also notes that no Constantinian monograms antedate 300 C.E. (Butler 1922, p. 181). 


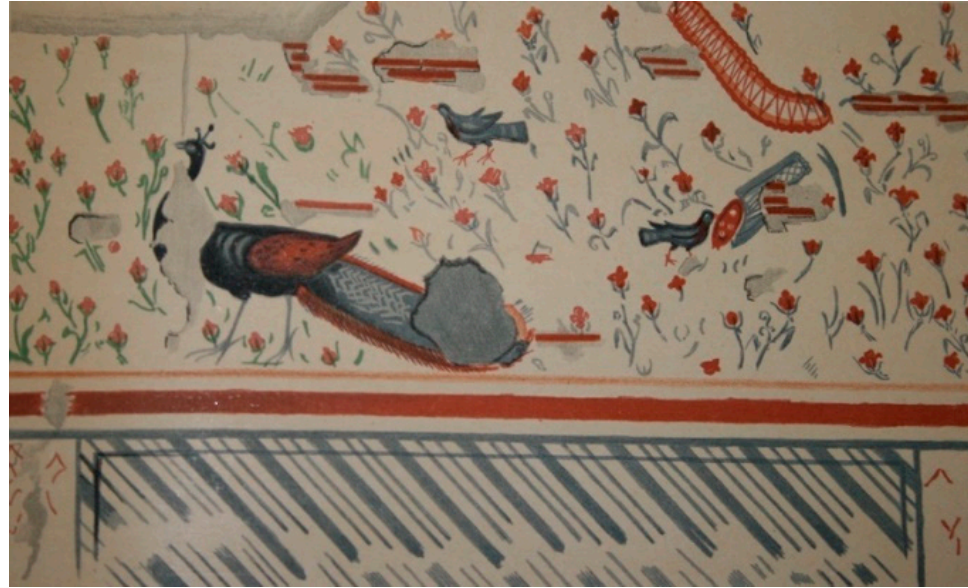

Figure 9. Sardis, "Painted Tomb" (Appendix A.2 T2), painting of south wall. (C) Archaeological Exploration of Sardis/President and fellows of Harvard College.

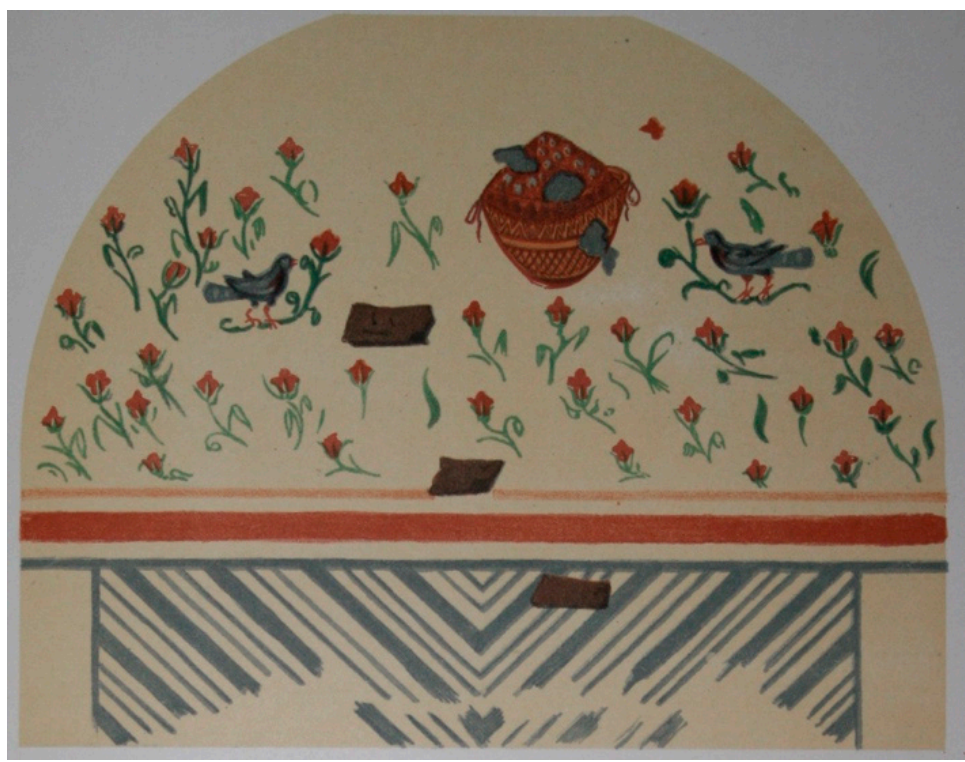

Figure 10. Sardis, "Painted Tomb" (Appendix A.2 T2), painting of east wall. @ Archaeological Exploration of Sardis/President and fellows of Harvard College.

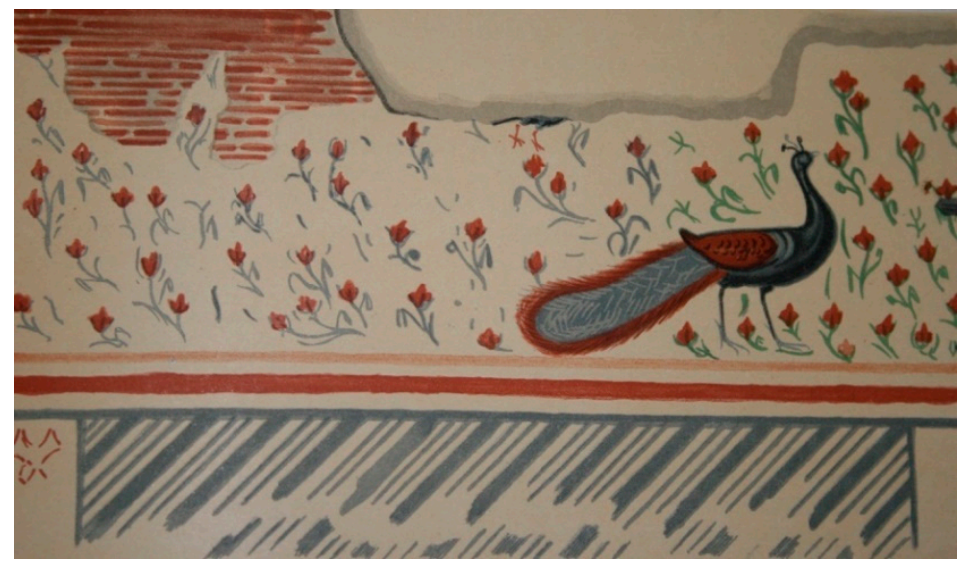

Figure 11. Sardis, "Painted Tomb" (Appendix A.2 T2), painting of north wall. (C) Archaeological Exploration of Sardis/President and fellows of Harvard College. 
The third tomb with a slight variation on the standard decorative program features the only human image among the Sardis hypogea. An androgynous encircled head possibly representing generic bounty or the passage of time decorates the vault of Tomb 07.3 (Figures 1 and 12-17). Damage to the top of the head makes it impossible to see if the head wore a crown of some kind, but vague painted greenery survives around the edges of the hair from the temple to the chin, suggesting an association with vegetation or the passing of time indicated by growing seasons. Once again, this special feature is classically rendered with much more skill in an observably different hand than the balance of the tomb's paintings. Identification is speculative, but the location and idealized countenance argue against a portrait of the deceased, in favor of a personification. ${ }^{16}$ Painted faces and busts commonly found on the ceilings of tombs and civic buildings include gorgons, gods, Christ, saints, or generic types representing the Seasons, Bounty or similar beneficent personifications. Like the Sardis head, identification of these generic types is challenging when clear iconographic indicators are absent.

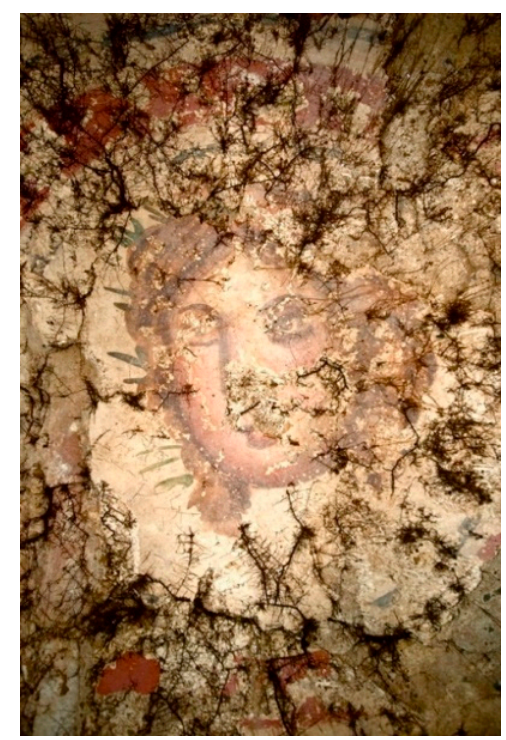

Figure 12. Sardis, Tomb 07.3 (Appendix A.5), vault. (C) Archaeological Exploration of Sardis/President and fellows of Harvard College.

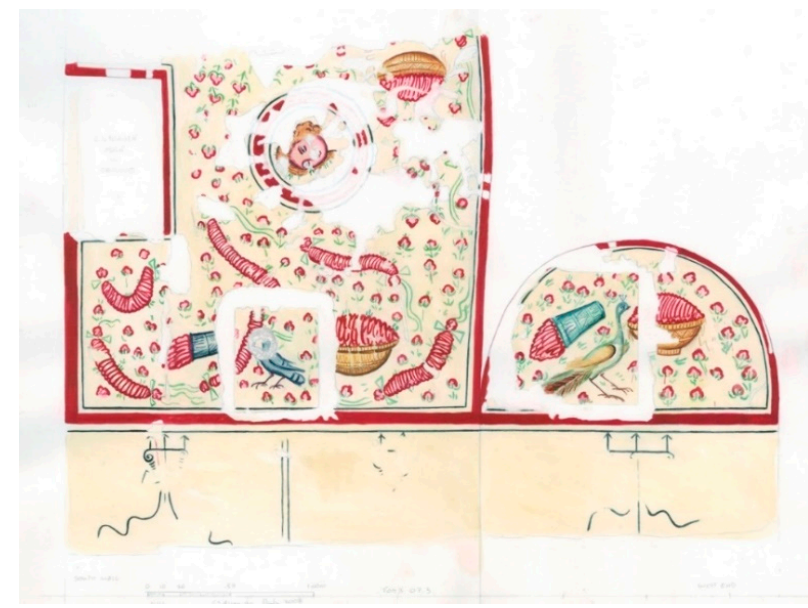

Figure 13. Sardis, Tomb 07.3 (Appendix A.5), painting of south and west walls and vault. (C) Archaeological Exploration of Sardis/President and fellows of Harvard College.

\footnotetext{
16 For example, the head at Abila that may represent the deceased or a deity (Barbet and Vibert-Guigue 1994, p. 170).
} 


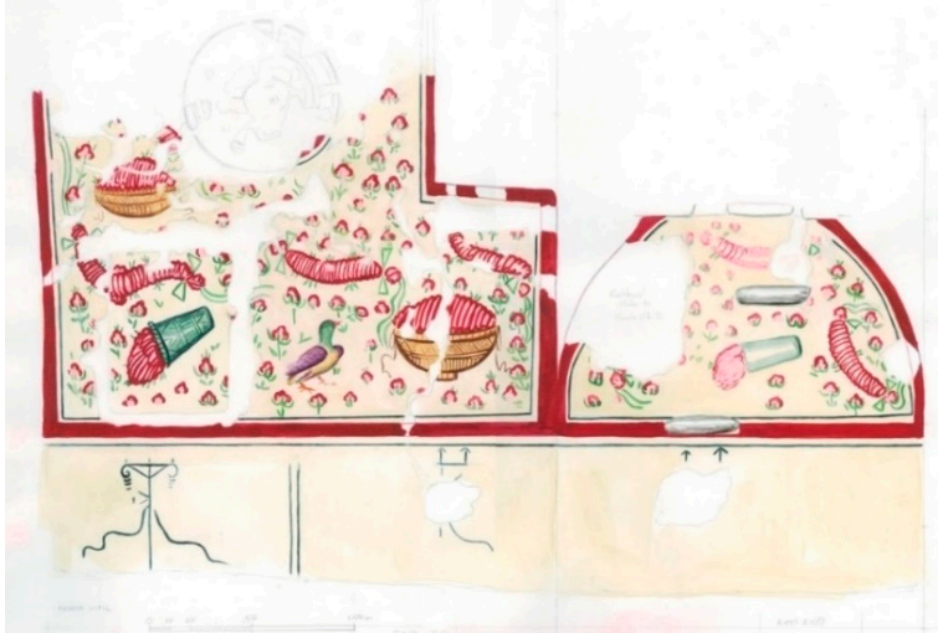

Figure 14. Sardis, Tomb 07.3 (Appendix A.5), painting of north and east walls. (C) Archaeological Exploration of Sardis/President and fellows of Harvard College.

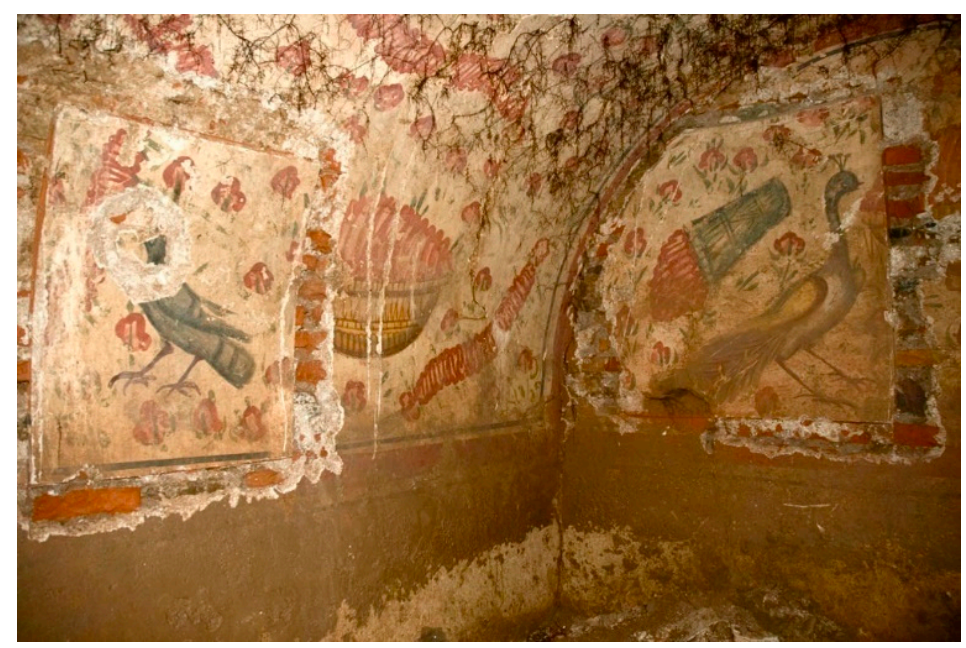

Figure 15. Sardis, Tomb 07.3 (Appendix A.5), south and west walls. (C) Archaeological Exploration of Sardis/President and fellows of Harvard College.

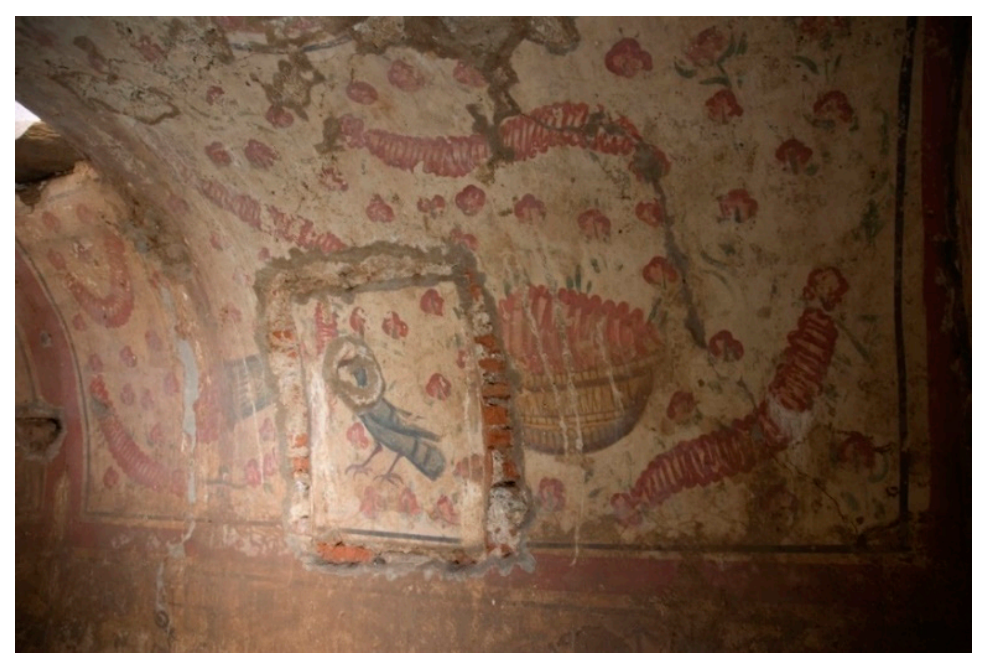

Figure 16. Sardis, Tomb 07.3 (Appendix A.5), south wall. (C) Archaeological Exploration of Sardis/President and fellows of Harvard College. 


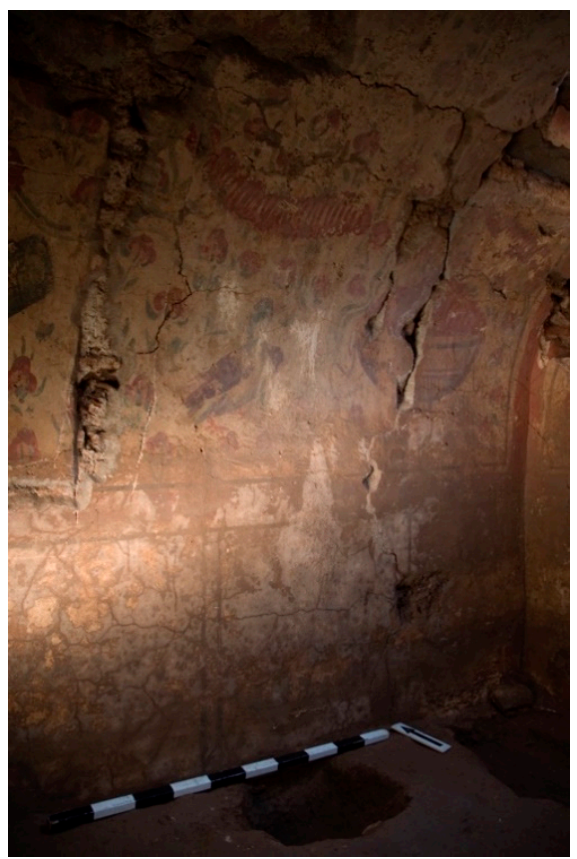

Figure 17. Sardis, Tomb 07.3 (Appendix A.5), north wall. (C) Archaeological Exploration of Sardis/President and fellows of Harvard College.

This head is perhaps best understood among allegorical images of the Seasons that became more common in funerary art by the early second century C.E. as representatives of time, symbolizing both its passing and life's blessings to be enjoyed. ${ }^{17}$ At the very least, they symbolized fertility and regeneration, bringing good fortune. As the imagery became pared down and multipurpose by the late third and fourth century, the "God of the year" or Zodiac god appeared alone or alongside the Seasons as personifications of annual bounty. ${ }^{18}$ The nonspecific nature of the Sardis head suggests interpretation as an allegorical personification of the Year, Time or Bounty, which then suggests both the passing of life and time, along with all of the benefits of nature compressed into one symbol enhanced by the surrounding images of Earth's bounty. ${ }^{19}$ The head in this tomb essentially reifies the ideas of bounty and time passing and is stylistically and compositionally in keeping with fourth century dates suggested by the Painted Tomb and Tomb of Chrysanthios.

The Kâgirlik Tepe tomb (Figures 18-22) was differentiated by the inclusion of a grapevine and a distinct painting style, indicating a different painter or workshop and perhaps a different date. This tomb includes the usual scatter of flowers, garlands, baskets, and peacocks, but no dado course. On the west lunette, flowers float behind birds perching on a grape vine. Like all of the motifs in the tombs, these vines have the potential to signal ritual significance, generic bounty or the blood of life. Vines evoke sacrifices and poured libations as well as joy in life and loss of the senses, all of which have powerful associations with death and rebirth. ${ }^{20}$

17 For example, Tomb B1 at Anamur includes portraits of the Seasons (Alföldi-Rosenbaum 1971, pp. 112-14), and several vaults in Isola Sacra tombs have personifications of the seasons in their corners (Calza 1940, pp. 141-42, Figures 67 and 68). Other examples include the cubiculum of the Seasons in the catacomb of SS. Pietro and Marcellino (Bisconti 2002, p. 97, Figure 109). For Seasons on marble reliefs and sarcophagi, see (Hanfmann 1952, p. 125ff).

18 Dunbabin argues that the God of the Year was added to Season images as a way to reinvigorate the now mundane images. She further argues that patrons chose this imagery as way to attract the bounty represented (Dunbabin 1978, pp. 158-61, 165).

19 As Maguire argues for personifications of Ge or Earth (Maguire 1990, p. 217).

20 Even in the pre-Christian period, wine was associated with blood and understood as the element that separates the dead and the living. Similarly, the appropriateness of vines for burial is also noted in Petronius, when Trimalchio asks his family to grow vines and fruit trees around his burial (Petronius, Satyricon 71, 11-12; Michaeli 2004, pp. 59-60; Cumont 1942, p. 491). 


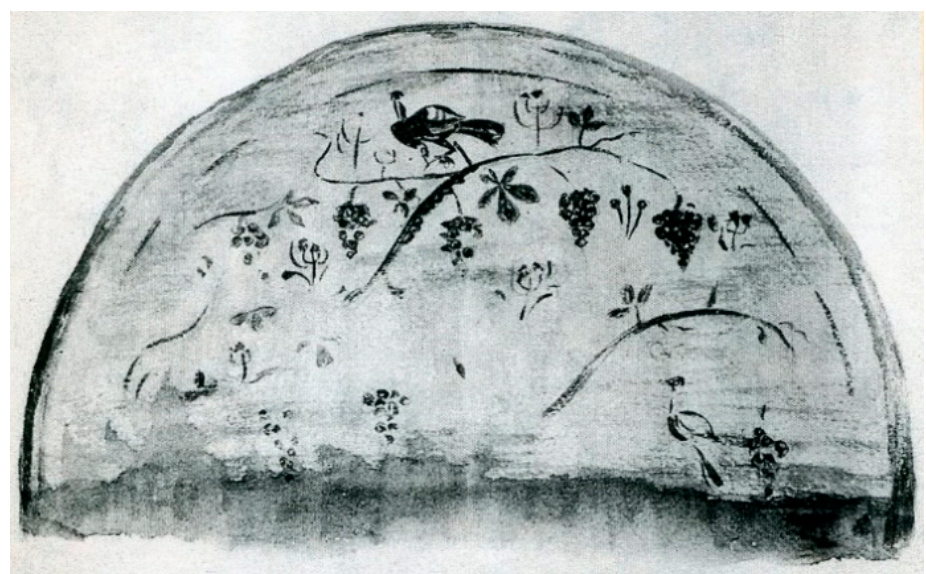

Figure 18. Sardis, Kâgirlik Tepe Tomb (Appendix A.7), painting of west wall. @ Archaeological Exploration of Sardis/President and fellows of Harvard College.

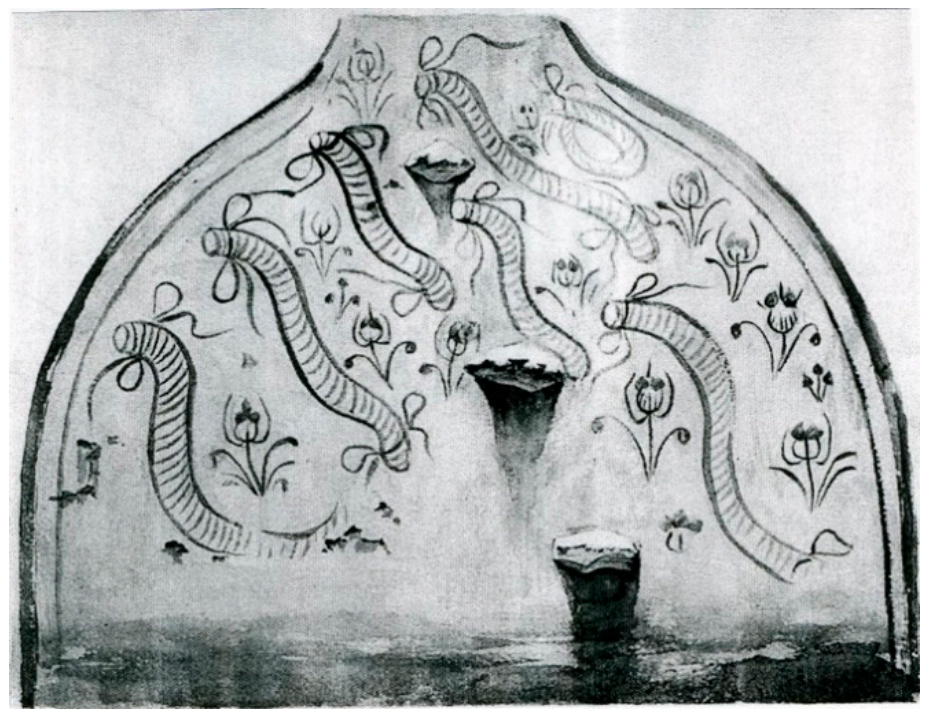

Figure 19. Sardis, Kâgirlik Tepe Tomb (Appendix A.7), painting of east wall. (C) Archaeological Exploration of Sardis/President and fellows of Harvard College.

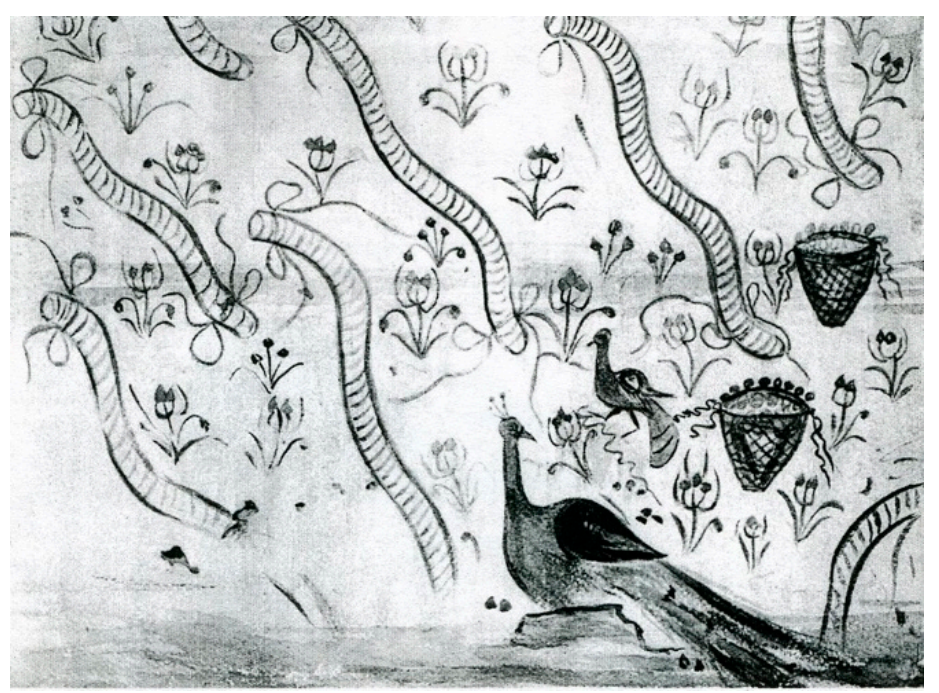

Figure 20. Sardis, Kâgirlik Tepe Tomb (Appendix A.7), painting of north wall. (C) Archaeological Exploration of Sardis/President and fellows of Harvard College. 


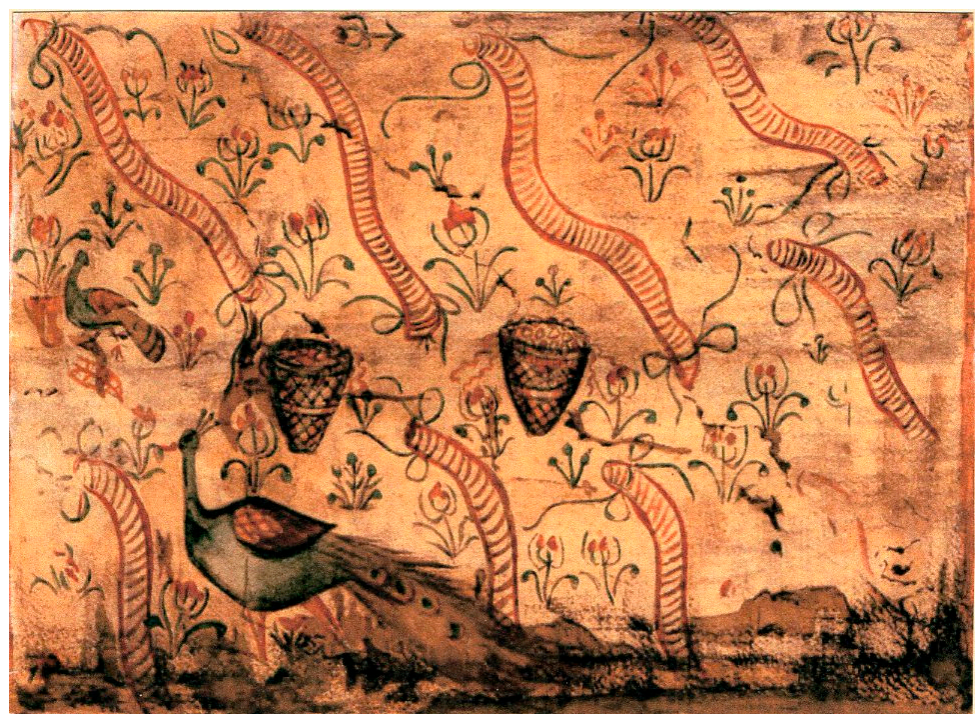

Figure 21. Sardis, Kâgirlik Tepe Tomb (Appendix A.7), painting of south wall. (C) Archaeological Exploration of Sardis/President and fellows of Harvard College.

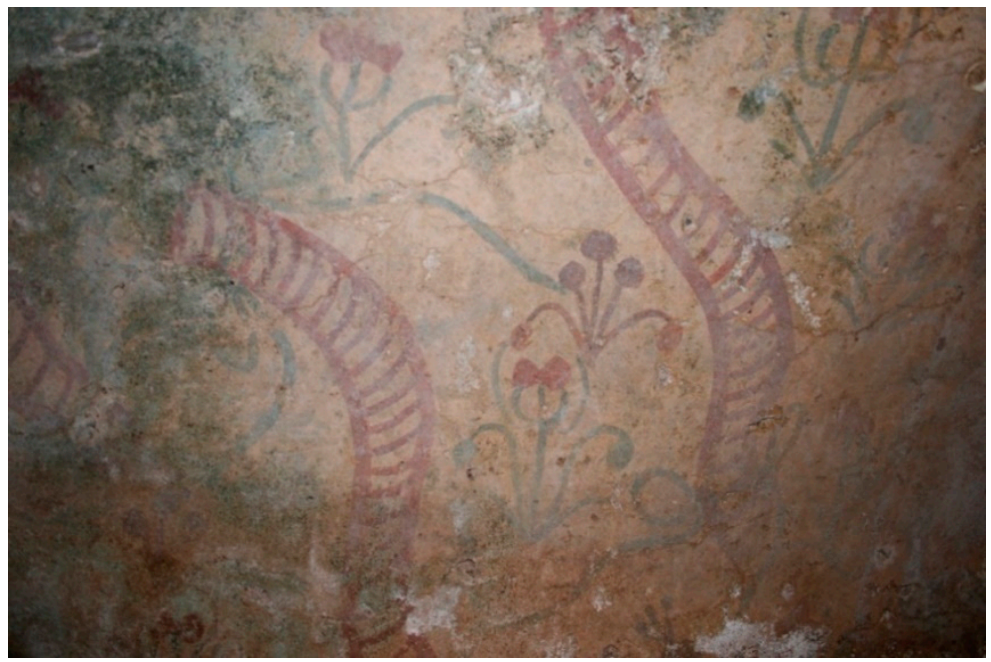

Figure 22. Sardis, Kâgirlik Tepe Tomb (Appendix A.7), detail. Author photo.

The painting style of the Kâgirlik Tepe tomb also distinguishes it from the larger corpus. The flowers are more linear, painted with thinner brushstrokes, with multiple small buds instead of simpler shapes like blooming flowers (compare Figures 15 and 21). While the irregularly scattered garlands in most of the tombs are far from naturalistic, the Kâgirlik Tepe garlands are merely striped tubes arranged in a very regular pattern. Rather than evoking irregularly scattered offerings, they create a textile-like repeated pattern. The overall composition of this tomb is largely the same decorative program as the other tombs. The style, like the inclusion of vines, suggests a painter tweaking or building upon an accepted decorative program. This implies decoration a bit later than the rest, but still within the timeframe when the basic program was relevant.

Two other tombs are stylistically exceptional to a greater extent than the Kâgirlik Tepe tomb, which may have implications for the internal chronology of the Sardis hypogea. Tomb 79.1 (Figures 23 and 24) also shares the basic compositional framework of the other tombs but with a more geometric approach, having almost completely abandoned the freehand painterly style of the other tombs. The garlands and baskets were outlined with a compass and detailed with regular crisscrossed striping. Birds are absent from Tomb 79.1, and the dado course is indicated only by an outlined frame. Tomb 79.1 clearly 
mimics the composition of the other hypogea, expressing an understanding of what tomb decoration should look like, suggesting that this was a late tomb, evincing a devolution of the tomb program down to its framing elements, or a slapdash attempt to quickly get something on the walls (such as the clumsily overlapping arcs visible in Figure 23). This happens to be the only tomb with datable grave goods, which set a terminus post quem of 392 C.E. ${ }^{21}$ This hypogea is perhaps slightly later than the majority of the corpus and represents either a later variation on the typical style or an amateur painter's attempt to recreate the expected decorative program.

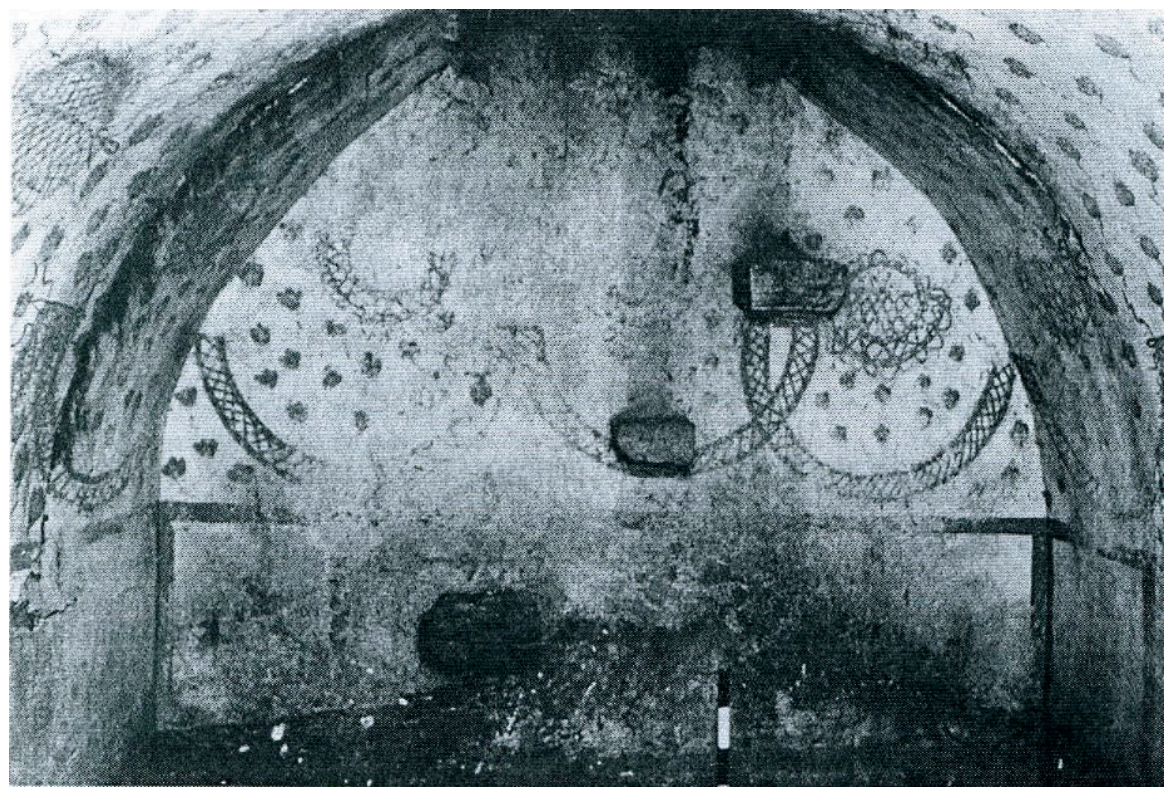

Figure 23. Sardis, Tomb 79.1 (Appendix A.8), east wall. ( ) Archaeological Exploration of Sardis/President and fellows of Harvard College.

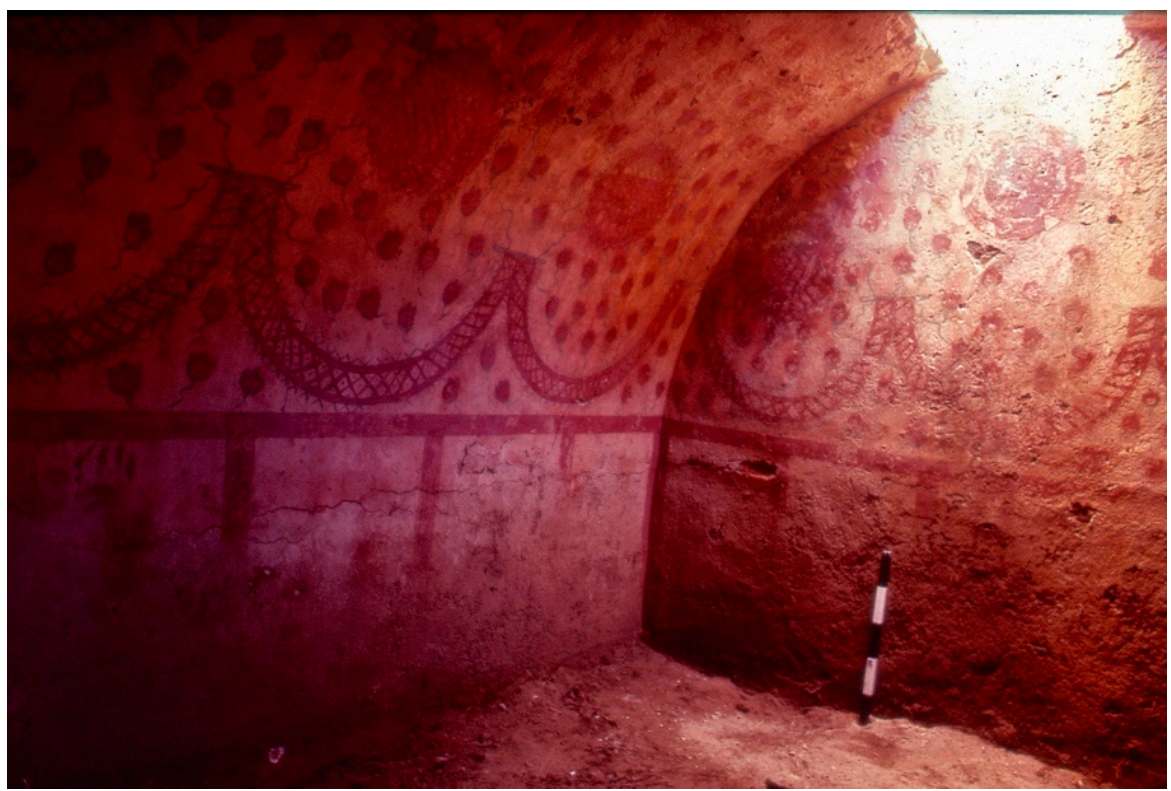

Figure 24. Sardis, Tomb 79.1 (Appendix A.8), southwest corner. (C) Archaeological Exploration of Sardis/President and fellows of Harvard College.

21 See Appendix A.8; grave goods include a coin of Valentinian II (375-92 C.E.) (Greenewalt et al. 1983, pp. 24-25). 
The Artemis precinct tomb (Figures 25 and 26) may be the latest of the Sardis painted hypogea, as it must date to the Christian phase of the former Artemis sanctuary, likely after the construction of Church $\mathrm{M}$ in the east corner of the temple c. 400 CE (Hanfmann and Mierse 1983, p. 195). The decoration is pared down to only the most basic elements: Red and black bands frame the dado area and curves of the lunettes with corner flourishes. ${ }^{22}$ On the west lunette, just left of center, a bird perches on a branch and nibbles at the branch's red and black buds (Figure 25a,b). This singular bird is perhaps a carryover from the birds so common among the Sardis tombs, but its solitary appearance and presumed Christian context suggest symbolic significance. Perhaps this bird is a dove symbolizing the Holy Spirit or the soul of the deceased. ${ }^{23}$ In any event, this tomb is the second that can reasonably be associated with a Christian occupant (along with the Painted Tomb) and the only one missing the freefield scattering of flowers associated with funerary and remembrance rituals.

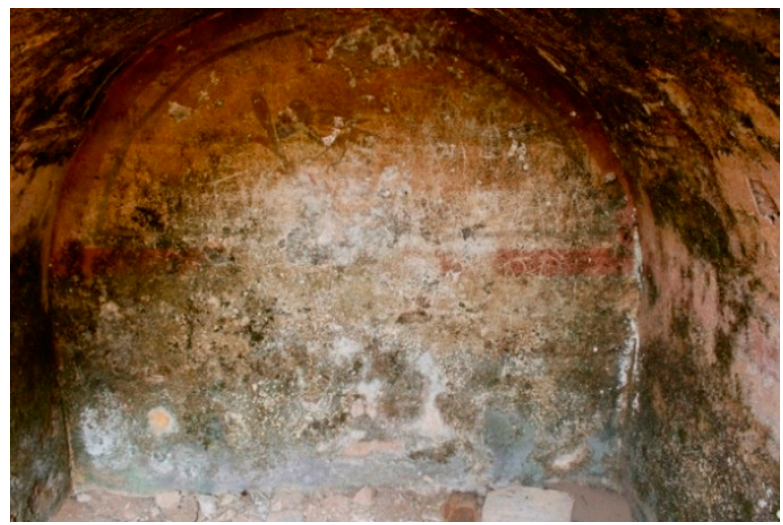

(a)

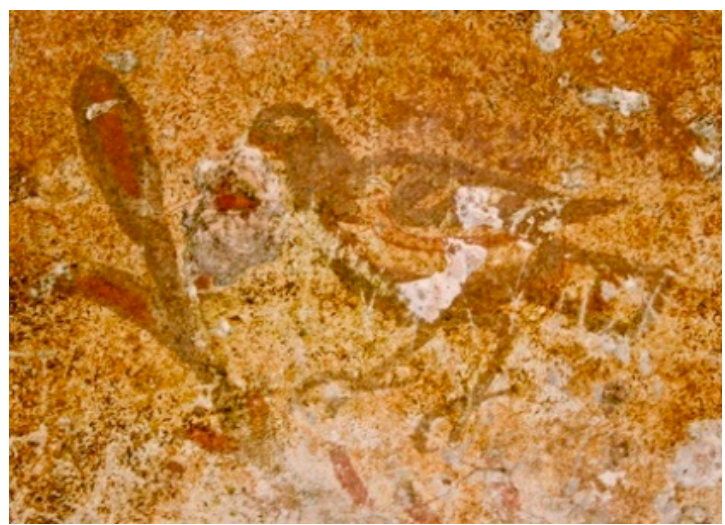

(b)

Figure 25. Sardis, Artemis precinct tomb (Tomb AT 2, Appendix A.10), west wall. (a) Longshot; (b) detail of bird in lunette. (C) Archaeological Exploration of Sardis/President and fellows of Harvard College.

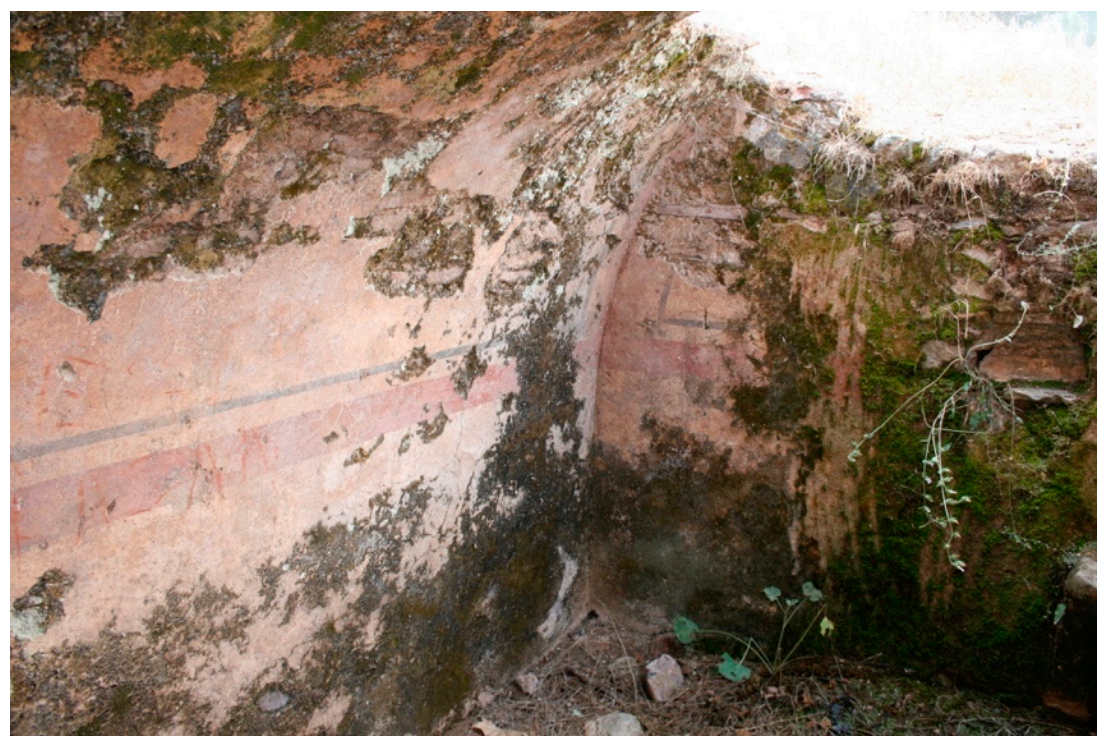

Figure 26. Sardis, Artemis precinct tomb (Tomb AT 2, Appendix A.10), northeast corner. (C) Archaeological Exploration of Sardis/President and fellows of Harvard College.

22 The corner flourishes are reminiscent of the domestic painting in MMS room 2 at Sardis.

23 Romans associated the dove with Venus, who is by extension a symbol of everlasting beauty and love. The dove of course became a symbol of the soul at peace early in the Christian period (Toynbee 1973, p. 259). 
The idiosyncrasies of these six tombs express the continuity and adaptability of this enduring regional decorative program. With the exception of the Chi-Rho monogram, all of the elements of Sardis' tomb iconography appear in sepulchral, domestic, civic, Jewish or Christian contexts throughout the Roman world. This borrowing and reinterpretation across media, types of spaces, and religions is indicative of the common visual language of the era and demonstrates that the Sardis corpus is more representative of a Greco-Roman cultural heritage than a particular religion. Logically, if the hypogea were built and decorated en masse, the workshop(s) would have been wise to choose imagery that could be as meaningful—or not—as possible to a range of potential buyers. ${ }^{24}$ Nevertheless, the program could clearly be personalized. Individual agency and choice were at play, but the variations reveal that there was also an expected repertoire that was the norm: a defined dado surmounted by an upper field populated by peacocks, songbirds, baskets, and garlands against a freefield scatter of flowers.

\section{The Broader Context: Painting Style and Comparanda}

The striking uniformity of the tomb paintings at Sardis indicates a distinct local tradition that is, in most cases, likely to be the work of a single workshop. Nevertheless, these paintings at Sardis reflect established styles and common iconographic elements from earlier and contemporary decorative arts across the Roman world. While comparanda are present in the vast corpus of catacombs in Rome, the Sardis paintings have their closest parallels in Anatolia, where hypogea show a preference for floral designs. ${ }^{25}$ Similar third-fourth century examples have been found in hypogea at Alaşehir-Philadelphia, Perge, Anamur, Zeugma, and Ephesus (Figure 27). ${ }^{26}$ The freefield floral style, which appears perhaps experimental, or at least variable at these other sites, became codified at Sardis.

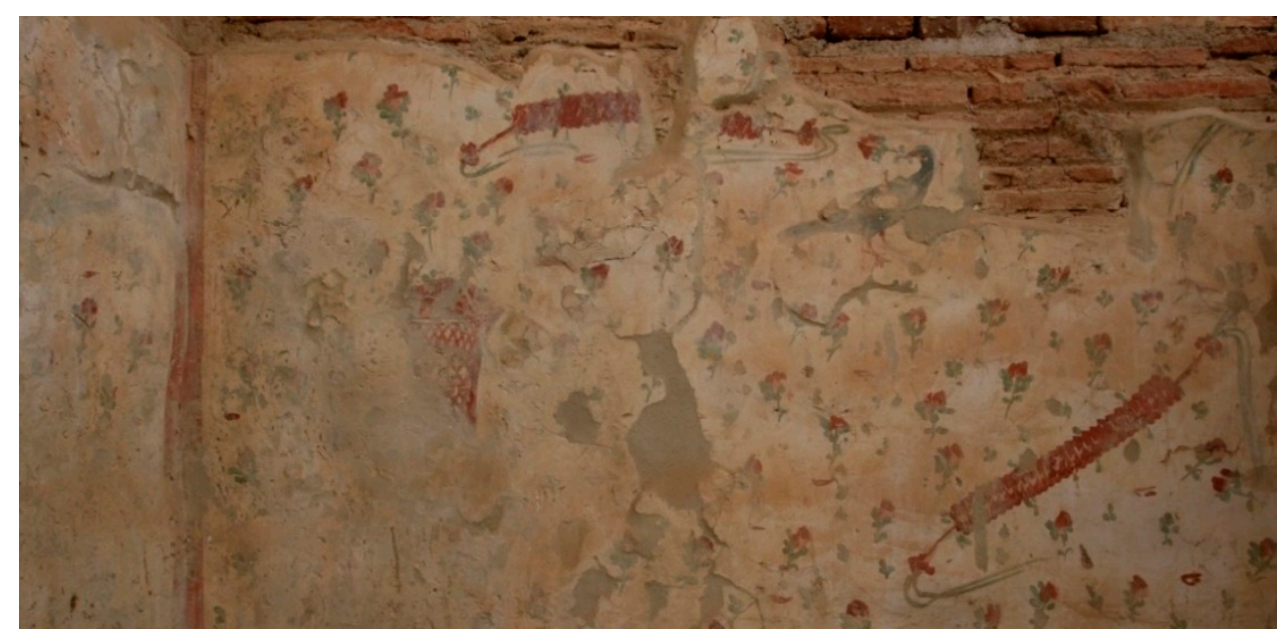

Figure 27. Ephesus, Hanghauser 2. Author photo.

In addition to lararia niches in the Bay of Naples, freefield scattered flowers appear as early as the first century C.E. in tombs in South Russia and the Levant (Rostovtzeff 2004; Barbet et al. 1997, p. 152). This style can be distinguished from more naturalistic garden compositions that recede into space or garlands and wreaths arranged as if hung on a wall as opposed to scattered on a field without perspectival coherence. Painted lararia contrasted the perspectival scenes so common on Pompeian

24 In the catacombs, tombs were roughed out and painted later, but the consistency of the majority of Sardis's painting suggests largely contemporary decoration.

25 Valeva noted that the hypogea of Asia Minor have more abundant floral designs, while Thracian examples prefer architectonic illusionism characteristic of the Constantinian era. Valeva also notes that hypogea with built-in steps are found in Greece as well as Asia Minor, but in Thrace, doors are built into the lateral walls (Valeva 1980, pp. 119, 125).

26 For Alaşehir-Philadelphia, see (Mellink 1977, Figure 37); for Perge, see (Deleman 2008, Figures 1 and 2); for Anamur, see (Alföldi-Rosenbaum 1971); for Zeugma, see (Kennedy and Kennedy 1998); for Ephesus, see (Zimmermann et al. 2011). 
walls by depicting scattered objects and figures, usually on a blank field. This conceptual approach affirms the idea of a supra-real area for interaction with gods and ancestors who did not exist in real, temporal space. By the third century C.E., scattered flowers had become a common painted decoration for household niches and small cubicula, perhaps as a natural evolution from painted lararia. This is also the era when the motif became common in hypogea, arcosolia or other niches in catacombs, which mimic such domestic spaces in shape and scale. The relative expediency of this sort of painting also makes it an efficient choice for these small, dark spaces. At Ephesus, freefield flowers are present by the third century in tombs including the Seven Sleepers Coemeterium, as well as in domestic spaces in the Hanghäuser, including niches, doorways, and small, dark rooms (Figure 27). ${ }^{27}$ At Sardis, this freefield floral painting is only extant in the fourth century hypogea. ${ }^{28}$ This may be indicative of specifically funerary associations for the style at Sardis or the happenstance of preservation. This relegation of freefield floral painting to tombs could also be a result of the late date when mature painting systems were adopted here, as current evidence suggests that this freefield painting program did not reach Sardis until fully codified and isolated by room and context, as much as a century after achieving popularity at other sites such as Ephesus.

As Rostovtzeff first noted, this freefield floral scatter recalls textile patterning. ${ }^{29}$ The two-dimensional, often very regular freefield scatter with token placement of other motifs evokes textile design and, like textiles, could express prestige while attracting bounty with propitious imagery. Gardens and floral imagery (illusionistic or not) could signify the otium associated with tranquility, peace, and retirement, as well as attendant luxury. These ideas might suit an ideal afterlife but were desirable associations for the living as well-and of course, images of the ideal afterlife were largely formed by conceptions of an ideal terrestrial life. ${ }^{30}$ In addition to luxury, textiles might evoke the intimacy of the home, and many of the domestic spaces with freefield decoration certainly contained textiles such as curtains or bed linens that may have visually echoed the images on the walls. ${ }^{31}$ The mirroring of designs between textiles, walls, and perhaps other objects is just the sort of consciously self-referential visual play that Romans delighted in.

As Maguire convincingly argues, domestic textiles were much more than decorative-they were also functional, with motifs chosen to promote security and prosperity. ${ }^{32}$ Birds, fruit, and vegetables are generalized and multivalent symbols with desirable associations with wealth, fertility, and the bounty of nature and beneficent or perhaps even apotropaic powers (Dunbabin 1978, p. 169; Maguire 1987).

27 Seven Sleepers is dated based on analogy, inscription letter forms, and textual formulae to the third century C.E., as is much of Hanghäuser 2 (Zimmermann et al. 2011, p. 158).

28 The only evidence for the freefield floral style at Sardis outside of tombs is a report indicating that fragments (now lost) very similar to the Peacock tomb came from an apse buttress wall of the fourth-century church EA and a few fragments from the Late Antique Wall and sector MMS 01.1. The fragments from the Late Antique Wall and MMS 01.1 are from fill, so the original context is unknown. On both fragments, the freefield design is painted on a c. $4 \mathrm{~cm}$ layer of plaster on top of an earlier layer of painted plaster. Since it seems highly unlikely that a tomb would have been redecorated, these may well have come from a domestic context and perhaps other examples will be revealed in the future (Rousseau 2010, cat. PB2, Figures 169, 159 and 160; Majewski 1973). Additionally, both funerary and domestic wall painting styles at Sardis lag behind Ephesus by about a century. For example, the third century funerary painting at Ephesus parallels Sardis' tombs from the fourth century, and Sardis's fifth-sixth century domestic painting resembles the fourth century Hanghauser 1 painting at Ephesus (Rousseau 2010, 2014).

29 Rostovtzeff argued that this "freefield" style (his "Floral style") was derived from carpets decorating nomadic tents. He documents this style across the ancient world beginning in the first-second century C.E. in both painting and mosaic, and he connects it to a Ptolemaic revival of ancient Egyptian art, also noting New Kingdom tombs at Sheikh Abd-el-Gourna near Thebes and domestic paintings at Amarna (Rostovtzeff 1919, pp. 151, 160-62).

30 Clarke suggests that floral imagery has less to do with paradise than a luxurious life (Clarke 2003, pp. 110, 207).

31 Note also John Clarke's "Tapestry Manner" (active from c. 250 B.C.E.-45 C.E.) among Fourth Style paintings, which borrowed compositions and motifs from carpets, arranging elements as flat frames on the wall surface (Clarke 1991, pp. 166-70). Additionally, references to the use of textiles in the home as prestige decoration became increasingly common in literary and visual sources from the fourth century forward, and it is clear that textiles were used commonly as curtains or doors as well as cushions and throws (Thébert 1987, pp. 388-89; Maguire et al. 1989, pp. 45-47).

32 The fact that motifs of animal and plant life (frequently including fruit) were meant to summon prosperity is proven by accompanying inscriptions on textiles, such as the invocation "flourish!" on one example and "EUPHORI" on a textile with a fruit-covered tree at the Boston Museum of Fine Arts (Maguire 1990, p. 217, Figure 8, p. 224). 
The potency or strength of images drawn from the natural world could vary depending upon context or repetition (Grabar 1992, p. 214). Both Dunbabin and Maguire have noted that most motifs in Late Antiquity had a wide variety of meanings depending upon context, but the confluence of multiple motifs increases the likelihood of a common structure of meaning (Maguire 1987, p. 3; Dunbabin 1978, pp. 164-65). Each of these motifs might be interpreted for iconographic associations with the hereafter, but presented together, their message seems to be one of more generalized beneficence. Flowers, garlands, birds, and baskets could summon prosperity and the security that prosperity brings, both for the deceased and for their mourners.

Similarly, the freefield decoration on tomb walls might have visually echoed textiles in the tomb, such as burial shrouds that covered corpses or textiles that served as canopies framing the burial space or lying-in-state. ${ }^{33}$ In addition, those scattered flowers could signal ephemeral floral offerings, the memory of those offerings, as well as the home of the living. The visual play of layered images in different media might then evoke connections to the home as well as the ritual of funerary offerings and all that embodied.

The two dominant motifs of scattered flowers and dado courses underscore the free movement between domestic and funerary imagery. Most motifs found in tombs are also found in houses, and both spaces were ultimately designed for social display. As noted, freefield floral painting is present only in tombs at Sardis, but this is exceptional. Nevertheless, both domestic and sepulchral painting at Sardis share architectural framing and dado courses. While the tombs' upper zones were not grounded in any spatial reality or sense of depth, the dado course and outlined lunettes reinforce the solidity of the wall. Here the value of convention and decorum are evident. To some extent, this relatively generic imagery may have been chosen out of habit, but the reference to domestic interiors connects the sepulchral space with lived environments. In addition to explicitly connecting the liminal space between the dead and the living, these framing devices augment the act of memory. As Elsner has argued, houses can serve as a framework for mnemonic devices and also embody the structure of thought. $^{34}$ The house form, then, both helped to create and recall memory. In practical terms, the tombs' painting programs reflect a fairly standard composition with motifs common to wall painting in a range of contexts that could be efficiently executed. But even if expediency fueled stylistic or compositional choices to some degree, that does not preclude semiotic significance for the imagery. The choice of design could be both practical and meaningful.

By the fourth century, scattered flowers had become ubiquitous in tombs from Rome to Anatolia. Given the burial context, the images might be interrogated for eschatological belief. The scattered flowers might represent an ethereal paradise, populated by symbols of plenty and prosperity, such as bountiful baskets and various birds. Peacocks might signal apotropaic protection, transformation, the beauty of God's creation, the heavens or immortality. ${ }^{35}$ Such an aspirational scene framed by the quotidian dado of a house then suggests a way for the deceased to keep one foot in each world-the earthly home of the living and paradisiacal gardens whose supranatural state is indicated by a lack of

33 Rostovtzeff notes examples of painted textiles on tomb vaults from Alexandria to South Russia and the Flavian Palace on the Palatine (Rostovtzeff 1919, p. 148), and Bisconti likens catacomb ceiling design to tents (Bisconti 2002, pp. 94-95).

34 See (Elsner 1995, pp. 77-78) on the function of the house as a rhetorical device.

35 The peacock was associated with immortality due to the annual shedding and regrowth of its feathers as well as the belief that its flesh did not decay (a theory tested by St. Augustine, De Civitate Dei, 21.4). By the late Hellenistic era, peacocks were associated with Dionysos and Juno, and apotheosis, used, for example, on coins minted to commemorate dead empresses (Maguire 1987, p. 39). Imperial poetry and literature associate peacocks and vegetal decoration with Elysium (Feraudi-Gruénais 2015, p. 443). In the Christian era, George of Pisidia (Hexaemeron, 1245-92) and Gregory of Nazianzus (Homilia XXVIII, 24) praised the peacock as the best of earthly creation, though it could also symbolize resurrection on Christian funerary monuments (Maguire 1987, pp. 39-40, n. 53-55). Dunbabin stresses context for determining the bird's significance. For example, the earliest examples of peacocks in mosaics appear in Dionysiac cult contexts, but when not accompanied by specifically Dionysiac imagery, such as torch-bearing erotes, the peacock simply represents beneficence, prosperity, and fertility (Dunbabin 1978, pp. 167-69). 
naturalism. ${ }^{36}$ This semantically generic imagery has comparanda across the wider Roman world and could easily suit the Jewish or Christian inhabitants of fourth century Sardis.

I suggest instead that the reasons for the choice of imagery are both simpler and more complex in their associations and intention: simpler because they reflect a common, standard style into which the viewer can read what they wish; and more complex because this multivalent imagery encodes a range of possible meanings into which the viewer can read what they wish. Considering that painted images addressed the living audience and required a viewer in order to become meaningful or active, we must consider how these images created meaning for that audience. Certainly, imagining a home for the deceased in a generic paradise might have comforted mourners. But this seemingly static imagery might instead be considered more active, as evocation of ongoing ritual action. The two are by no means mutually exclusive, and these images can be read to evoke the beneficence and prosperity hoped for in this life and in the hereafter alongside the funerary rituals designed to foster remembrance and affirm social roles and processes. ${ }^{37}$ We can understand the tomb as a space of active interaction designed to make a variety of connections possible.

\section{Funerary Ritual}

The spatial and ritual frame of the tomb reflects the complex processes at play with regard to dealing with this most common of experiences. As Platt observed, tombs both helped to define and challenge metaphysical boundaries and functioned as a liminal space where the living might symbolically communicate with the dead via ritual (Platt 2012, p. 217). Funerary rituals help mourners to mediate an uncomfortable transition fraught with grief, loss, longing, uncertainty, and fear of mortality. Such rituals present a mechanism through which to perform grief and fulfill social roles by affirming group life and social ties. ${ }^{38}$ Occasional literary and visual references create a picture of Roman funerary practices that were likely practiced to varying degrees across the empire and into the Christian era: After the body and grave gifts were interred, the silicernium, or funerary meal, was eaten graveside, and the cena novendialis marked the end of the official period of mourning after nine days. The dead were visited again with offerings of food, flowers, and often graveside meals on the occasions of their birthdays and the festivals of Lemuria, Parentalia, Violaria, and Rosalia. ${ }^{39}$ The names of these festivals, ancient testimony, as well as tomb imagery suggest the scattering of flowers as part of these commemoration rituals. ${ }^{40}$ The freefield scatter of flowers and garlands painted on Sardis's tombs closely mimics the gesture of flowers thrown across the body, strewn over the earth, or even through the tomb vault. ${ }^{41}$

The painted image is thus commemorative and performative for living mourners. The performance, or externalization of inner trauma moves individual concerns to the space of collective experience, making personal loss relevant to the larger community. The act of offering affirms collective, repetitive processes that were part of Roman tradition and commemorative practices. The creation of images was

36 Feraudi-Gruénais applies the idea of "supra-natural" imagery transcending the natural world to "landscapes that seem to portray neither reality nor myth" (Feraudi-Gruénais 2015, p. 443).

37 Connerton and Davies outline the role of commemorative rites as expressions of identity that reaffirm social ties and continuity with the past (Connerton 1989, pp. 41-71; Davies 2002).

38 Denzey Lewis describes gift giving as a way to "redefine or reinscribe social relations among the living" (Denzey Lewis 2013, p. 124) and notes that offerings may represent the performative act of making or offering, rather than the deceased's "direct relationship with the object." (Denzey Lewis 2013, pp. 127-28). See also (Gee Forthcoming).

39 Epigraphic sources also reference honoring the birthday of the deceased with gifts of roses in perpetuity. CIL V. 7454/ILS 8342; CIL V. 4489; CIL V. 7906/ILS 8374; CIL VI. 96.26; CIL X. 5835; Epigraphica 52 (1990) 171-74 (Carroll 2006, p. 42, n. 60). Jones notes that the literary references for these festivals date primarily to the upper classes of the first century B.C.E. and the first century C.E., but archaeological remains suggest widespread practice on some scale among all classes and into the Christian period (Jones 1987, pp. 813-14).

40 Barbet also notes that the earliest examples of the scattered flowers come from first century lararia at Pompeii, with funerary examples appearing by the early second century at Som (Barbet 2014, pp. 201-3; Von Hesberg et al. 2015, p. 246).

41 Compare, for example, the effect of flowers thrown through the Pantheon's oculus at Pentecost. 
part of this commemoration and ongoing memorial process. ${ }^{42}$ The earliest extant examples of freefield flower painting come from lararia, which also received offerings on an ongoing basis. Continuity was important for connecting with the deceased and with the divine, and this stability was expressed via processes and images that remain relatively constant into the Christian era and in religiously plural funerary environments. The existing ritual environment of the Mediterranean world where Christianity took hold must be the starting point for the ritual plurality of Early Christian death and burial, which essentially modified inherited practices. ${ }^{43}$ A number of sources associate roses or violets with the deceased or their place in paradise, but surely funerary practice inspired these iconographic explanations. ${ }^{44}$ Gee, Denzey Lewis, and others have noted the need to separate social practice and afterlife belief when considering funerary gifts or imagery (Gee Forthcoming; Denzey Lewis 2013, p. 123). The freefield flowers in funerary painting might be best understood as the material memory of ephemeral funerary ritual. This does not exclude other potential readings, but eschatological significance need not be the primary interpretation. Combined with garlands, wreaths, and baskets of food or flowers, the image of scattered flowers might preserve memories, suggest offerings in perpetuity or aspirational hopes for an eternal spring or paradisiacal afterlife. Furthermore, funerary rituals and grave offerings and decoration functioned as symbolic capital to mark status and luxury for the deceased and for the living. These ideas are not mutually exclusive and signal the multivalent potential of such imagery and its resonance among the living and in funerary and domestic spaces.

The activities that took place within the tomb and the living actors who activated and responded to the imagery are important for considering the intention or purpose behind decorative choices. Post-burial visits to graves are better understood in the context of tombs above ground or larger spaces, such as catacombs. The actual practice of tomb visits is less clear for Sardis. The built-in steps documented in almost all of the hypogea suggest the intention to allow multiple visits. ${ }^{45}$ While this is certainly possible, climbing in and out remains an inelegant business, and the prospect of well-dressed visitors carrying offerings down seems unlikely. There is evidence that a few of the tombs included multiple interments, meaning that some were revisited at least to add bodies, though it is not at all clear whether this was the norm. ${ }^{46}$ Nevertheless, commemorative visits to the burial site would not necessarily require mourners to actually descend into the tomb. We might well imagine cepotaphia, or tomb gardens, planted above the Sardis hypogea. ${ }^{47}$ The tombs could function as sites of memory and aspiration - potentially general or specific-regardless of whether their interiors were revisited. The freefield imagery might evoke floral offerings whether they were strewn flowers or planted gardens. In either case, the images evoke ongoing growth, ritual, and connection to the living for each individual.

\section{Conclusions: Sardis' Wall Painting in the Context of Late Antique Art}

In many ways, the Sardis freefield tomb paintings are typical of broader trends in Late Antique imagery. The motifs themselves are frustrating in their religious and iconographic ambiguity but in this way speak to the syncretism and multivalence of imagery in Late Antiquity, with polysemic

42 Denzey Lewis describes tombs as “... 'memory theatres'—space deliberately constructed in order to provoke, organize, broadcast and sow memories in the minds of visitors" (Denzey Lewis 2016, p. 267). See also (Gee Forthcoming) on funerary imagery and iconography as well as the relationship between the dead and the living.

43 See (Volp 2002, p. 268; Denzey Lewis 2016, p. 267), among others.

44 An epitaph of Ausonius encourages adding roses to ashes and suggests an association with eternal spring and thus life beyond the grave (Kay 2015, no. 8, p. 85; Toynbee 1971, p. 63); additionally, epitaphs often mention the desire of the deceased for his or her ashes to transform into violets or roses (e.g., Servius En.: V, 79: VI, 221), and CIL: IX, 3184 states that "this flower is Flavia's body" (Michaeli 2004).

45 Steps were not documented in the HoB and Pactolus Cliff hypogea, but this is likely due to speedy excavation or the happenstance of preservation.

46 Tomb 79.1, the only unrobbed hypogeum, contained two bodies that were either buried simultaneously or within a generation of one another; and the "Peacock tomb" contained the body of an adult in a recessed "sarcophagus" depression in the floor along with dispersed bones from other (presumably later) burials.

47 Cepotaphia are documented elsewhere by (Feraudi-Gruénais 2015, p. 444; Toynbee 1971, p. 97). 
symbols primarily reflecting a shared Greco-Roman cultural heritage whose meanings were shaped by the viewer and context. The tomb decoration proves once again that the particulars of religious faith were often subsidiary to Roman cultural identity, and imagery was freely exchanged between the religions of antiquity. As Zimmermann (2015, p. 453) has noted, "Christianization of burial customs and funerary art is characterized in equal parts by innovation and continuity, and therefore represents a typical example of the complex transformation process of Late Antiquity." Thus, reading images for religious or eschatological belief is often unproductive. Sardis' tomb imagery is better read as evocative rather than symbolic, signifying remembrance and connection via ritual gesture.

This discrete corpus expresses the role of burial imagery that may reflect ongoing ritual action. The tomb imagery could reflect ritual negotiation between the living and dead as opposed to a "completed" burial event. Ritual action would reinforce the continuity of the funerary and ongoing memorial process while providing a locus for grief and loss that spoke to individual and communal needs. The specificity of a particular individual was subverted to the cultural role of the deceased as a symbol of family and community protected via ritual action. Like funerary rituals, the tomb itself emphasizes both connection and separation between living and dead, simultaneously asserting communication and defining potentially permeable boundaries. ${ }^{48}$ These boundaries were philosophically permeable, as eventually, the roles of mourner and mourned would shift, but this space could remain a site of memory, interaction, and affirmation of filial and social ties.

Just like domestic imagery, funerary wall painting required a spectator to receive and activate imagery. Decoration addressed the living audience, and all images have relevance and comparanda in the world of the living. Tombs too were socially engineered spaces employing prestige indices for the benefit of the deceased and the living and emphasizing convention and continuity much more than change. Wall painting has the potential to represent complex ideas about the real and metaphysical worlds, as it both affirms the wall surface and challenges its veracity. The Sardis tomb compositions speak to that mutability: spaces grounded in the "real" architecture of the domestic domain of the living alongside the fantastic, supra-real world that a mourner would literally climb out of after immersion into the ritual funerary space.

Painted decoration both affirms and denies the imitated world while embodying an array of semiotic references. ${ }^{49}$ In the Sardis hypogea, the painted dado affirms the veracity of the built wall surface, while its frank two-dimensionality denies the reality of those "marble" blocks. Birds and baskets interspersed with freefield flowers suggest a garden, but the compositional style signals a supranatural space. Perception of semiotic references is subjective, with compositions and imagery that can signal multiple ideas. For example, peacocks could be associated with immortality, or the beauty of creation-or both.

Roman art includes a series of semantic systems chosen to convey ideas of decorum, or style appropriate to the circumstance. The freefield floral scheme was not a poor attempt at naturalism but a deliberate reconstruction of a ritual moment. Likewise, the planar, two-dimensional approach to the wall surface was an intentional component of much Late Antique painting. The abandonment of illusionism affirmed the solidity of the wall by acknowledging the two-dimensionality of the wall surface, both affirming and toying with reality. The Roman delight in visual interplay is evident here: between real and fictive; between the natural and created worlds; between illusionism and acknowledgement of perceptual processes that controlled the natural world; between action and stasis; between the living and the dead.

48 See also (Platt 2012, p. 220).

49 For example, Elsner presents the ideas that illusionistic Roman wall paintings (1) give the viewer a piece of the world imitated; or (2) deny the viewer the world imitated because it is false. The truth, according to Elsner, is that the viewer's relationship with painting is subjective, and the viewer's desires and responses move across a continuum between these two extremes (Elsner 1995, pp. 74-75). See also (Elsner 1995, 2007; Hölscher 2004). 
The painting program reflects the syncretism and polyvalence of ideas and iconography in the Late Antique period. Within this framework, the imagery can be understood as visually and intellectually open with multiple responses and interpretations possible. The lack of specificity allowed for a wider range of symbolic interpretations. Vague semantic content was suitable for spaces of the dead but lacked any specific connection to eschatological belief and was ultimately grounded in relevance to the living and the supranatural space of funerary practice. Imagery is perhaps better understood in terms of evocation and response, rather than singular iconographic meaning Symbolic images of ritual processes were activated by the viewer within a framework reflecting the continuity, innovation, and experimentation of Late Antiquity. In this context, the Sardis tomb paintings can be understood as layered images meant to evoke general beneficence in this life or the next, as well as ritual acts of remembrance via motifs and strategies common to the arts of Late Antiquity.

Funding: This research received no external funding.

Acknowledgments: I would like to thank the Archaeological Exploration of Sardis and especially Nicholas Cahill, Marcus Rautman, Catherine Alexander and Brianna Bricker for access and support of my research at Sardis. I am also grateful to Regina Gee, Norbert Zimmermann and Alix Barbet for their insights and suggestions about this material.

Conflicts of Interest: The author declares no conflict of interest.

\section{Appendix A Catalogue of Painted Hypogea at Sardis 50}

\section{Appendix A.1 T1. The "Tomb of Chrysanthios" (Tomb 76.1), Figures 3-751}

Measurements: $3.2-3.4 \mathrm{~m}$ long by $2.75-2.85 \mathrm{~m}$ wide by c. $2 \mathrm{~m}$ high.

Orientation: north-south (entrance at north end).

The Tomb of Chrysanthios was built over a Roman cist grave that had been cut through a seventh-sixth century B.C.E. Lydian domestic wall, probably with knowledge of the earlier tomb (Greenewalt 1977, p. 105). Remains of bone in the earth above the hypogeum attest to the disturbance/looting of the tomb, and the only remains were an undecorated lamp and a small pile of disintegrated bones (Greenewalt 1979, pp. 3, 7). The construction is typical of Sardis hypogea: a slightly irregular rectangle with a barrel vaulted roof, and three steps in the north wall for entrance from roof. ${ }^{52}$ The tomb is built from field stones and mortar, with hard lime arricio plaster containing gravel, chunks of stone, broken tiles, pot sherds, chunks of lime, charcoal, and straw-like material covered with lime intonaco plaster, both of varying depths due to stone construction. The interior was painted a secco, probably with lime putty as medium, and incised sketches are visible in places, as are $1-2 \mathrm{~cm}$ brush strokes. ${ }^{53}$

A dado with alternating panels of striped and brecciated simulated marble is topped by a freefield composition of peacocks, doves, baskets, cornucopiae, wreaths, and scattered flowers in panels framed by thin black and broad red bands. The simulated marble represents three varieties: Panels of straight vein diagonal stripes of bands of gray and blue in a broad-narrow-narrow sequence alternate with panels of contiguous irregular yellow ovals (some outlined in red with black centers), and panels of diagonal serrated vein bands of dark green on black-pale green-paler green (Figure 4).

This tomb is most notable for the three wreathed inscriptions on the west, east, and south walls and fragments of a fourth in the center of the vault (Figures 4-6). ${ }^{54}$ As noted above, these suggest

50 Please note that the T1-T12 designations come from (Rousseau 2010).

51 The Chrysanthios Tomb (Tomb 76.1) was discovered in 1976 (Greenewalt and Mellink 1977, pp. 308-10, Figure 19; Greenewalt 1978, pp. 61-64, Figures 5-7), then excavated in 1977 (Greenewalt 1979, pp. 4-9, Figures 3-5; Greenewalt 1977, p. 105). See also (Hanfmann 1981; Hanfmann and Mierse 1983, p. 208, no. 4, 208; Majewski 1977).

52 The arc of the vault is greater at the entrance end (angle more acute) and does not bond with the rest (Greenewalt 1979, p. 5).

53 Majewski report quoted in (Greenewalt 1979, p. 6).

54 Only a few letters survived from the vault (Greenewalt 1979, p. 5). 
that Chrysanthios himself may have painted parts of the tomb and that it may have been intended for multiple burials. The inscriptions also help establish a late fourth century date for the tomb.

\section{Appendix A.2 T2. The "Painted Tomb," Figures 8-1155}

Measurements: unavailable.

Orientation: east-west.

The painting program is strikingly similar to the Tomb of Chrysanthios: A dado of gray-blue striped simulated marble is surmounted by a freefield design of scattered flowers garlands, baskets, and birds (peacocks and perhaps doves). Also like Chrysanthios' tomb, the lunette opposite the entrance (in this case, the west wall) features a wreath with trailing ribbons (Figure 8). This wreath encloses a Constantinian Chi-Rho monogram flanked by Alpha and Omega. The Christogram is rare in Late Antique paintings but, when datable, is rarely earlier than the mid-fourth century. ${ }^{56}$ The open Rho is characteristic of eastern examples of salutare signum, and the square Omega is common in third and fourth century inscriptions, supporting a fourth century date for the tomb. ${ }^{57}$

\section{Appendix A.3 T3. The "Peacock Tomb" (Tomb 61.14), Figures A1 and A2 $2^{58}$}

Measurements: $3.06 \mathrm{~m}$ long by $2.33 \mathrm{~m}$ wide by $1.91 \mathrm{~m}$ high

Orientation: east-west (entrance at east)

This hypogeum was built over first-second century C.E. Roman tile graves in a Roman cemetery and reused into the seventh century. ${ }^{59}$ The vault had been pierced in the northwest corner in antiquity and water seepage obliterated much of the painting with brown stains. The dado, separated from the floral panels by violet and ochre bands, was too poorly preserved to be reconstructed. The paintings on the west wall were completely destroyed. In 1969-1970, the remaining paintings were removed to the Manisa museum. ${ }^{60}$

This tomb has some subtle but unusual details. First, there was apparently a wider palette, including lime white, carbon black, light and dark red earth, yellow ochre, umbers, green earth, and granular Egyptian blue. There was also a variety of flowers. Not only were there two distinct styles, but the more regular type for Sardis, with three green sepals, and a pink base topped by tri-lobed red is in some cases elaborated in this tomb as in no other with extra leaves/branches (Figure A2). In addition, a second variety has a gray stem with two gray leaves and a flower with four petals, each a different color (gray, dark red, pink, blue). Many of this last style have above them two downward curving lines, a chevron and a dot executed in gray. The similarity in shape, if not style, with this type in the Peacock Tomb and the flowers/buds in the Kâgirlik Tepe tomb is striking (compare Figures 21 and A2).

55 This tomb is first mentioned in (Butler 1913, p. 478) and discussed more fully by C. R. Morey in (Butler 1922, pp. 174, 181-183, ill. 18, color pls. IV-V). The tomb was vandalized in 1913 and is now lost beneath a farmer's field—only the paintings published in Sardis I remain. The Painted Tomb is \#3 in (Hanfmann and Mierse 1983, p. 208).

56 A notable exception is the Iznik Tomb, dated to the first third of the fourth century (Barbet 2007, p. 138).

57 Morey also notes that no Constantinian monograms antedate 300 C.E. (Butler 1922, p. 181).

58 The Peacock Tomb (Tomb 61.14) was excavated in 1961 (Hanfmann 1962, pp. 30-33, Figure 26), which is the presumed date for Donald P. Hansen's undated "Peacock Tomb" report (Hansen n.d.). The removal of the frescoes was covered by Majewski in (Hanfmann 1970, pp. 56-58, Figures 44 and 45). See also (Hanfmann 1972, p. 89; Hanfmann and Mierse 1983, pp. $205,207,208$, no. 7 ).

59 The body of an adult around 60 years of age was found in the floor along with dispersed bones from other burials. Coins found in the earth range from Honorius (393-423) to Phocas (602-610). The tile graves are graves 61.24 and 61.25 and the 60-year-old in the "sarcophagus" built into the floor is grave 61.14 (Hansen n.d., p. 1; Hanfmann and Mierse 1983, p. 208).

60 These were given catalogue numbers WP 61.1 E, WP 61.1 N and WP 61.1 S, respectively (Majewski 1970, pp. 57-58). 


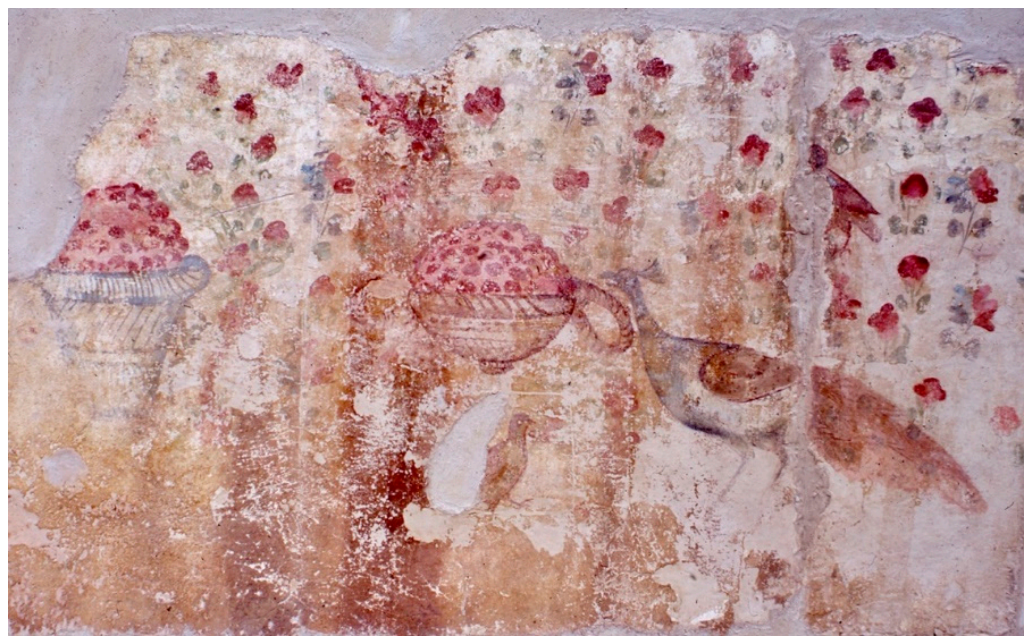

(a)

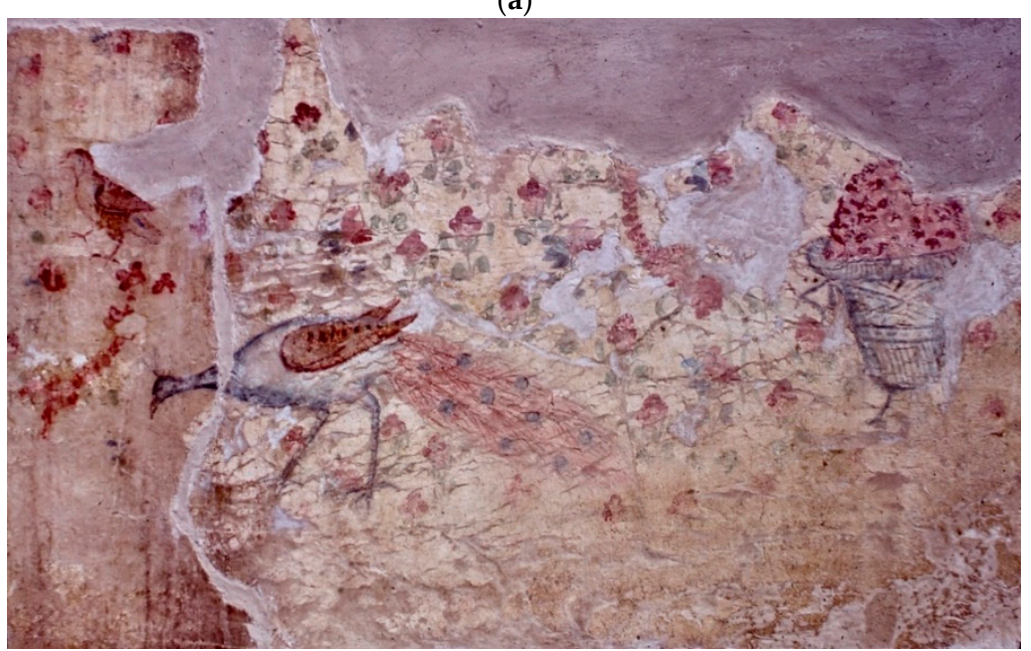

(b)

Figure A1. Sardis, "Peacock tomb" (Tomb 61.14, Appendix A.3), sections removed to the Manisa museum, (a) north wall; (b) south wall. (C) Archaeological Exploration of Sardis/President and fellows of Harvard College.

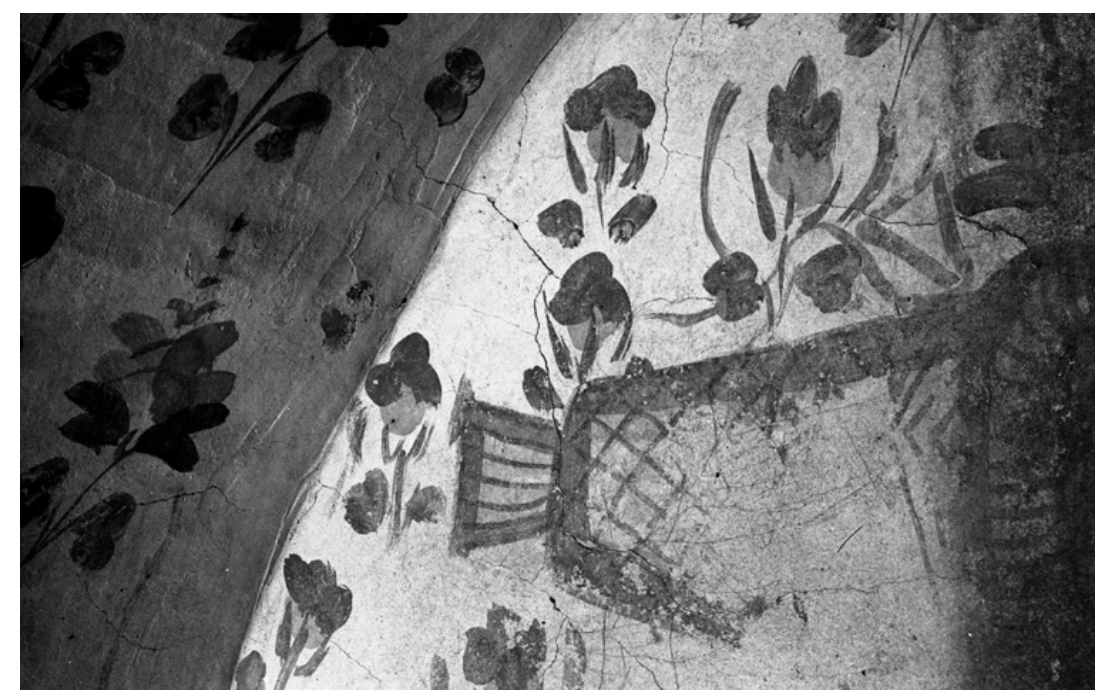

Figure A2. Sardis, "Peacock tomb" (Tomb 61.14, Appendix A.3), detail of northeast corner. (C) Archaeological Exploration of Sardis/President and fellows of Harvard College. 
Appendix A.4 T4. Tomb 93.1, Figures A3-A561

Measurements: $2.80 \mathrm{~m}$ long, 2.29-2.34 m wide, century $2.15 \mathrm{~m}$ high.

Orientation: east-west.

This hypogeum was discovered during the winter of 1992-1993 and excavated by the Manisa museum. The top of the west wall and vault had been pierced at the time of discovery, and no objects or bones were recovered (Greenewalt et al. 1995, pp. 1-2). The walls were plastered and painted with the usual freefield composition primarily in shades of dark blue, green, pink, and red above a poorly preserved dado course comprising a rinceau pattern with arrows (Greenewalt et al. 1995, p. 2).

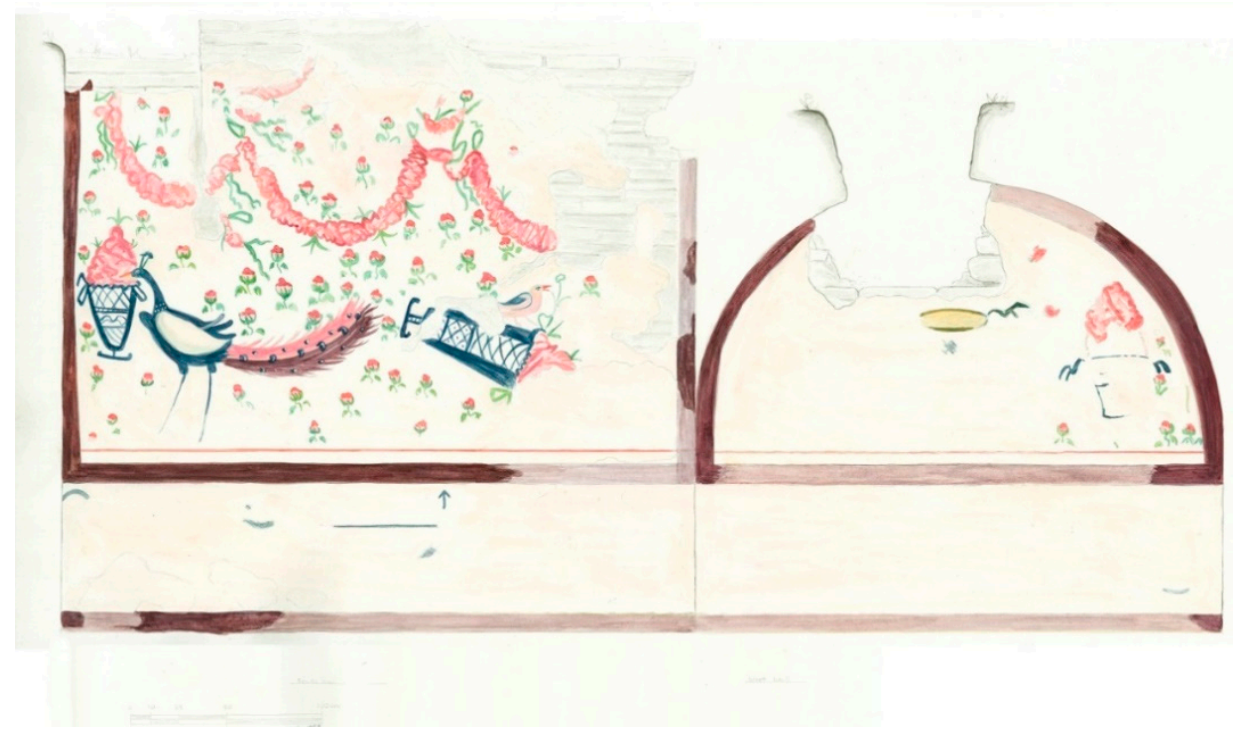

Figure A3. Sardis, Tomb 93.1 (Appendix A.4), painting of south and west walls. (c) Archaeological Exploration of Sardis/President and fellows of Harvard College.

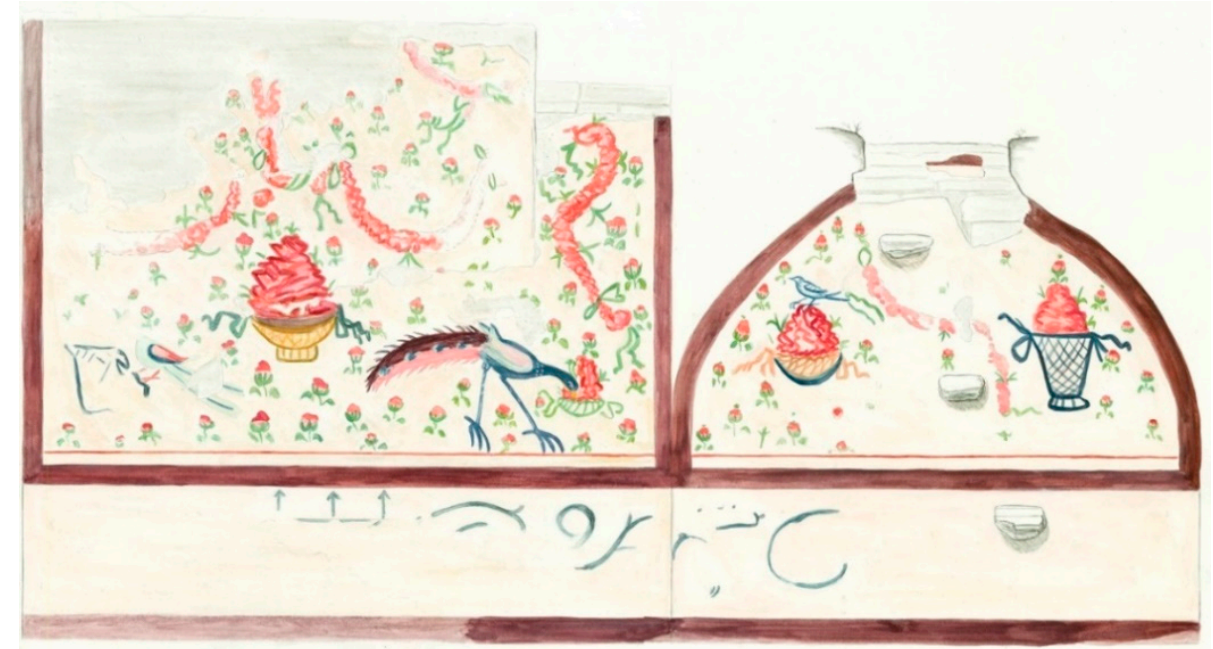

Figure A4. Sardis, Tomb 93.1 (Appendix A.4), painting of north and east walls. (c) Archaeological Exploration of Sardis/President and fellows of Harvard College.

61 Published in (Greenewalt et al. 1995, pp. 1-3, Figure 2). 


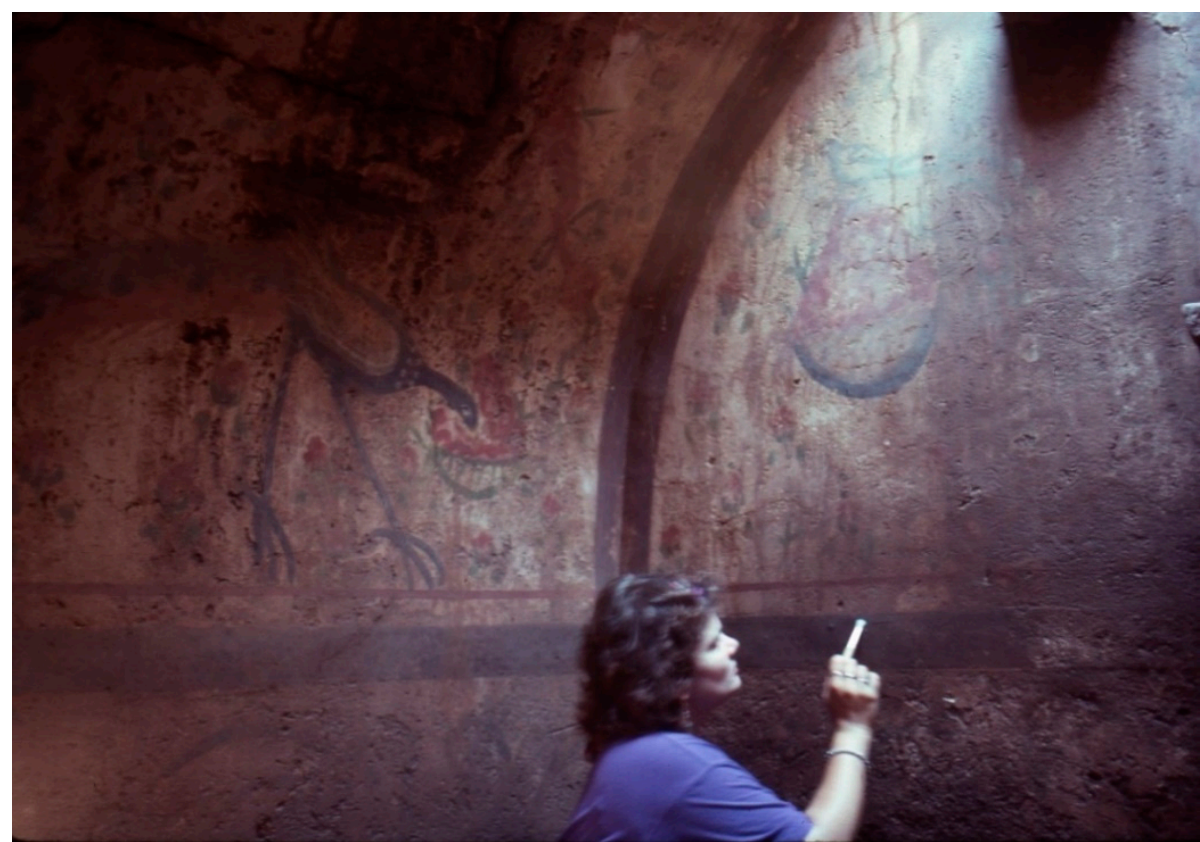

Figure A5. Sardis, Tomb 93.1 (Appendix A.4), northeast corner. (C) Archaeological Exploration of Sardis/President and fellows of Harvard College.

Appendix A.5 T5, T6. Tombs 07.2 (Figures A6-A8) and 07.3 (Figures 1 and 12-17)62

Measurements: 07.3 is $2.82 \mathrm{~m}$ long by $2.05 \mathrm{~m}$ wide and $2.23-2.335 \mathrm{~m}$ high.

Orientation: east-west.

These two hypogea share a common wall. A workman informed the Sardis Expedition of adjacent tombs 07.2 and 07.3 in August of 2007, and they were excavated in 2008. Both tombs are the rectangular barrel-vaulted hypogea common at Sardis. Both tombs had entrance holes covered by schist slabs at the east end, with three cantilevered steps built into the wall. Looters had entered tomb 07.2 by removing the schist slab covering its entrance hole, then tunneled through the west wall into tomb 07.3.

Tomb 07.2 is painted only with strewn red flowers and accordion-style garlands with trailing ribbons framed with a thick band of dark red-purple around the wall joins (lunettes) and delineating a dado area.

Tomb 07.3 (Figures 13-17) has the same background of flowers and garlands as 07.2, with the addition of peacocks and smaller birds, baskets, and the head painted on the vault discussed above. Wide, dark red bands outline the lunettes of the short walls and delineate a dado level from the upper field. This dark red is the same color as the red used for the flowers and garlands in both tombs, as opposed to the more purplish color of the frame in 07.2. Thin black lines frame the red on all sides and traces of incised guidelines are visible in the plaster. The west wall has a peacock between an overturned blue basket and an upright brown basket, both filled with highly stylized red fruit or flowers. The south wall has a blue bird (perhaps a peahen), and the north wall a duck. Both birds are situated between two baskets much like those around the peacock on the west wall. All of the birds are painted in shades of blues, purplish-brown and yellow. The dado level has the remains of a rinceau and arrow pattern (perhaps candelabra) painted in black much like the dado of tomb 93.1.

The head is in the center of the vault, framed by concentric circles of black, dark red, and black, possibly representing a Season or Personification of the Year (Figure 12). The head is of strikingly finer quality than the rest of the painting, suggesting a different hand or at least much greater care.

62 These tombs have not yet been published. The information is based on my observations of the paintings and ( $\mathrm{D}^{\prime}$ Angelo 2008). 


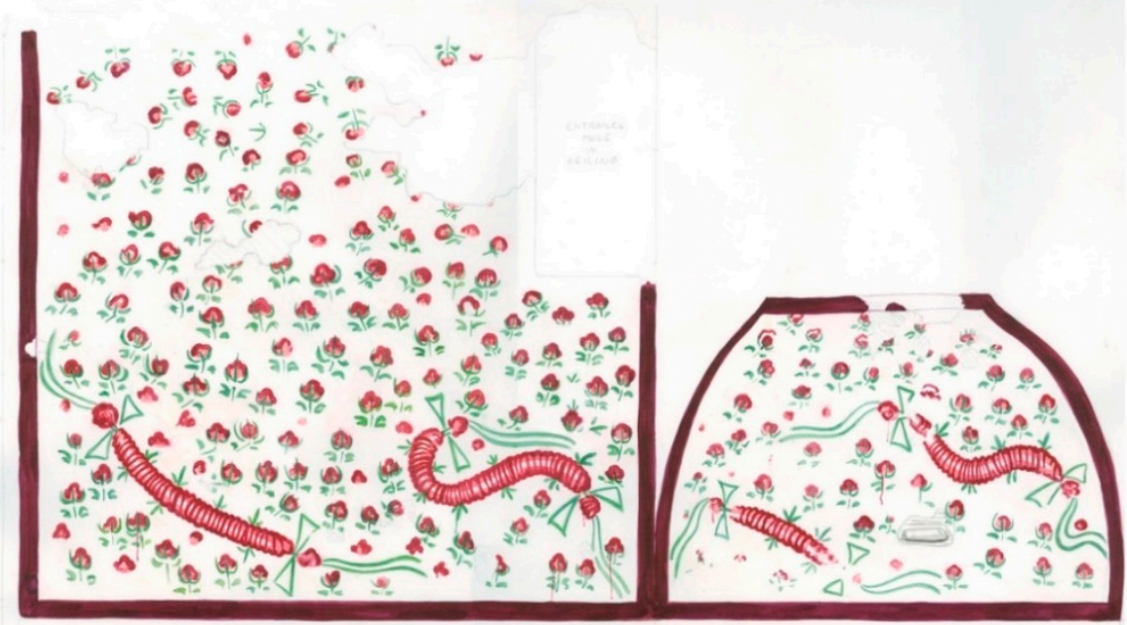

Figure A6. Sardis, Tomb 07.2 (Appendix A.5), drawing of north and east walls. (C) Archaeological Exploration of Sardis/President and fellows of Harvard College.

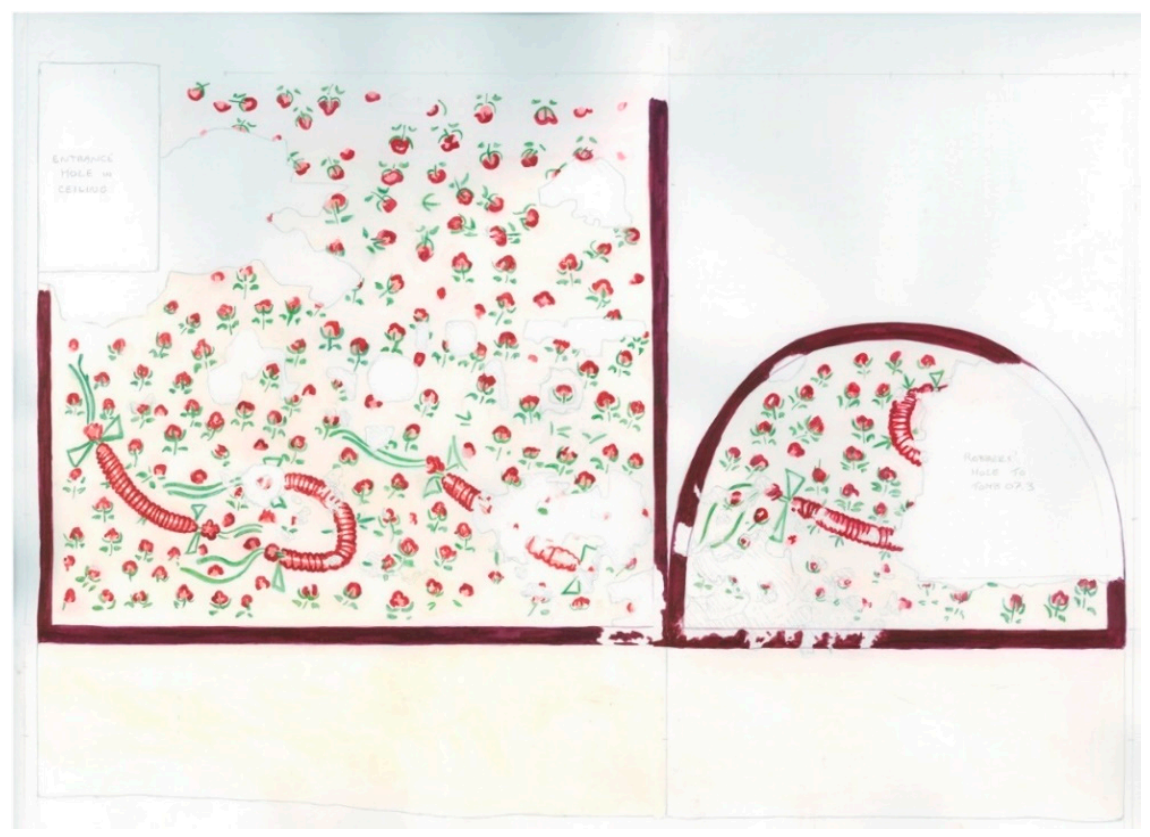

Figure A7. Sardis, Tomb 07.2 (Appendix A.5), drawing of south and west walls. (C) Archaeological Exploration of Sardis/President and fellows of Harvard College. 


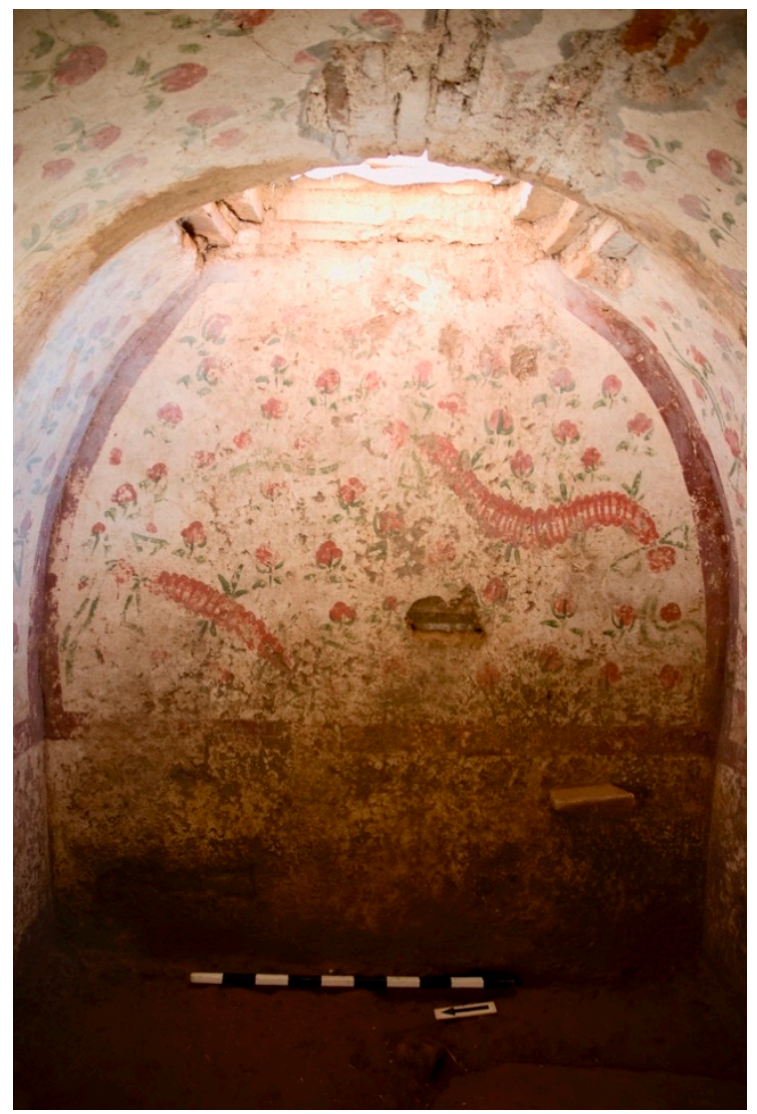

Figure A8. Sardis, Tomb 07.2 (Appendix A.5), east wall with cantilevered steps and entrance above. (C) Archaeological Exploration of Sardis/President and fellows of Harvard College.

There are signs of burning and pottery fragments in both tombs. Two coins were discovered in Tomb 07.03 , of third-fourth century date. ${ }^{63}$ Scattered bones recovered from the tombs suggest that the occupant of 07.3 was a man, and the occupant of 07.2 a woman (D'Angelo 2008, pp. 2-3).

These hypogea were almost certainly constructed at the same time, as they share a wall and are aligned with one another, though 07.3 is slightly smaller. They might have been painted at different times, even though they share many of the same painted motifs and basic palette. Cathy Alexander (2008), Sardis' illustrator, noted that the background color of tomb 07.2 is almost pure white, as opposed to the warm yellowish shade of the background in tomb 07.3. The inner pink of the blooms in 07.3 is a lighter pink than in 07.2. In addition, the lunettes of 07.2 are outlined in a single broad swath of purplish red as opposed to the brighter red accompanied by a thin black line in tomb 07.3.

\section{Appendix A.6 T7. 79.2, Figures A9-A11 ${ }^{64}$}

Measurements: 79.2 is $2.51-271 \mathrm{~m}$ long by $2.11-2.17 \mathrm{~m}$ wide and $1.87 \mathrm{~m}$ high.

Orientation: north-south, entrance at north end.

63 Coin 2008.0017 is probably 3rd-4th c., and Coin 2008.0018 is a coin of Caracalla according to numismatist Jane DeRose Evans.

64 Tombs 79.2 and 79.3 were excavated during the campaign of 1979 (Greenewalt et al. 1983, p. 22, Figure 26). Tomb 79.2 is also published as the "Tomb excavated by K.P. Erhart in 1979" in (Hanfmann and Mierse 1983, p. 208, no. 9). 


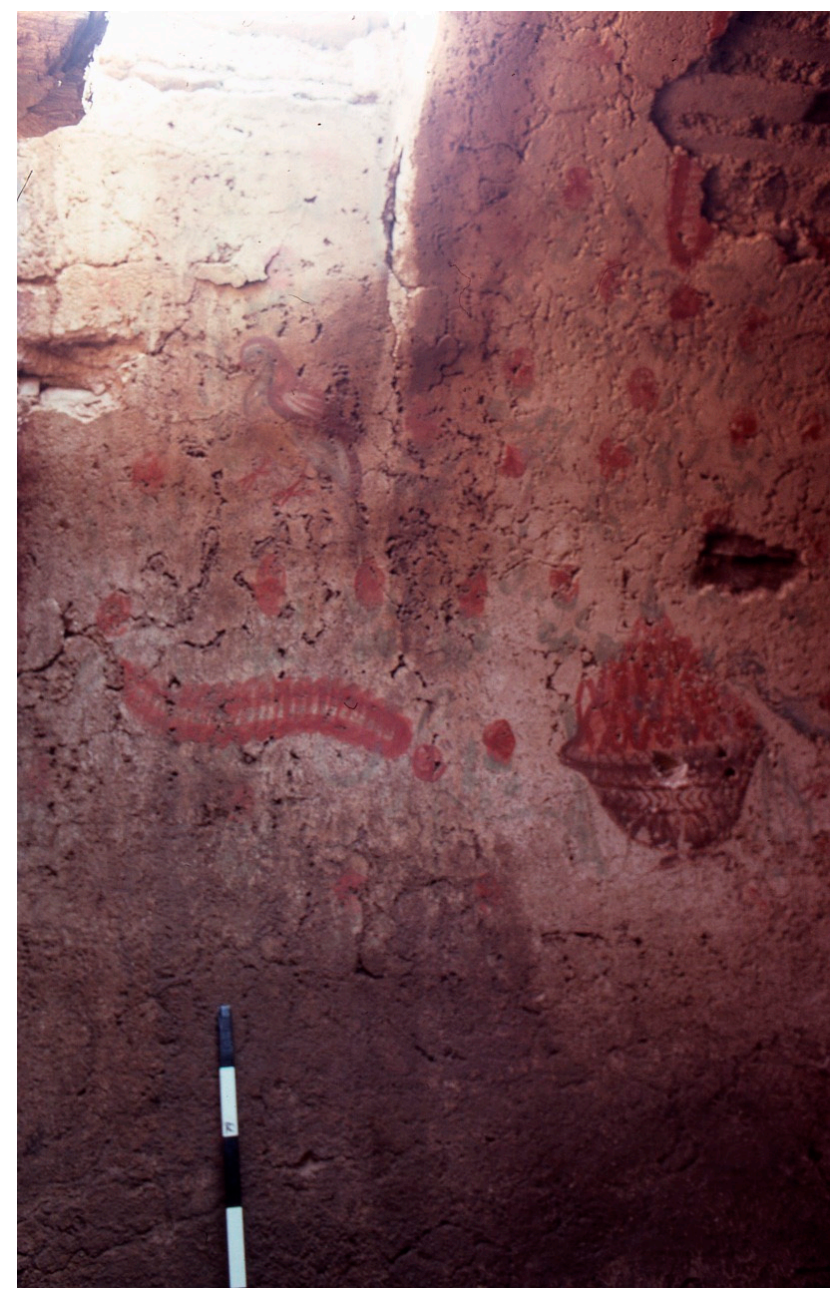

Figure A9. Sardis, Tomb 79.2 (Appendix A.6), east wall. (c) Archaeological Exploration of Sardis/President and fellows of Harvard College.

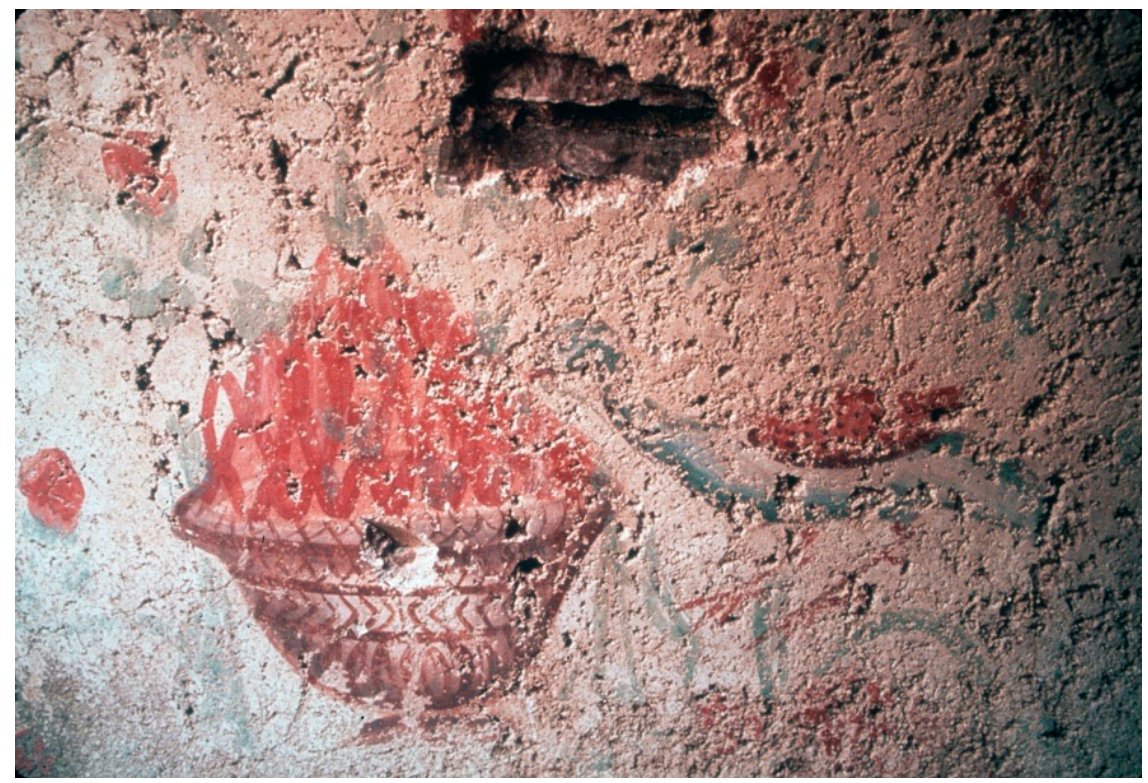

Figure A10. Sardis, Tomb 79.2 (Appendix A.6), detail of east wall. (C) Archaeological Exploration of Sardis/President and fellows of Harvard College. 


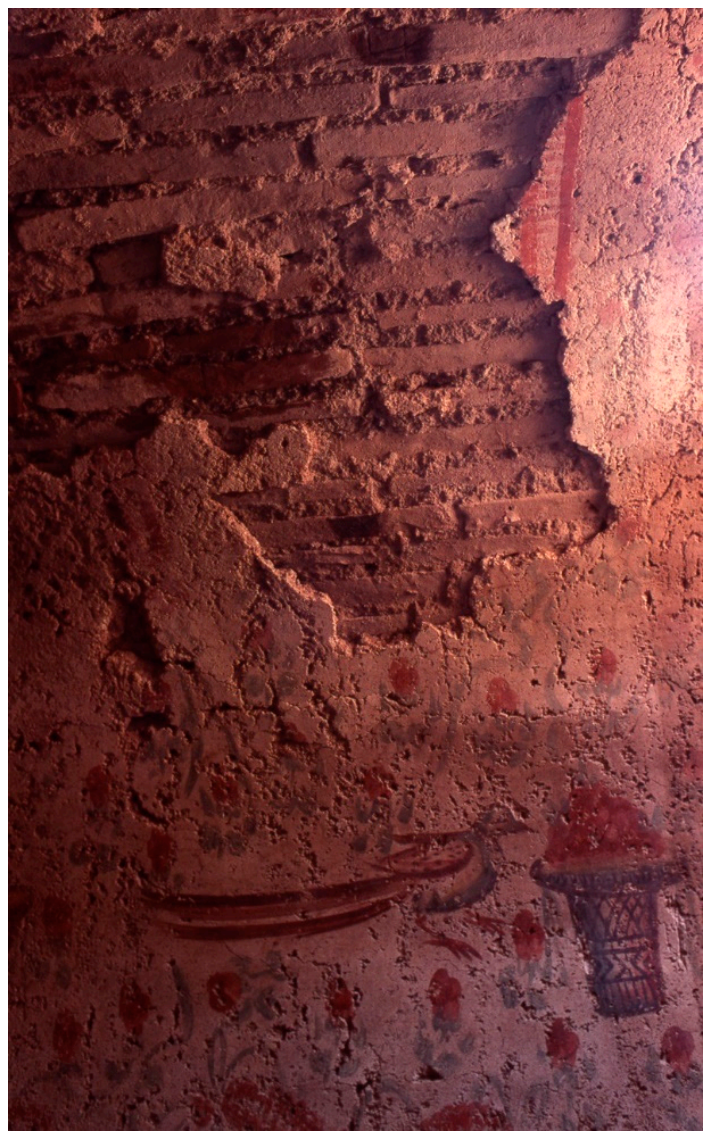

Figure A11. Sardis, Tomb 79.2 (Appendix A.6), west wall. (C) Archaeological Exploration of Sardis/President and fellows of Harvard College.

79.2 shares a common wall, but not quite the same orientation, with unpainted and unplastered hypogeum 79.3. ${ }^{65}$ The paint in tomb 79.2 is only preserved on about one-third of the wall space, but a dark red dado band runs along all four walls with freefield flowers, garlands, pheasant-like birds and partridges above, including at least one garland or wreath on the vault. ${ }^{66}$

There were no small finds in 79.2, though the paintings as well as the sparse grave goods in the adjacent tomb 79.3 support a fourth century date. ${ }^{67}$ A Byzantine "tea cup" contained charcoal and ash perhaps from an offering or incense (Erhart 1979, p. 5).

\section{Appendix A.7 T8. Kâgirlik Tepe Tomb, Figures 18-2268}

Measurements: $2.68 \mathrm{~m}$ long by $2.43 \mathrm{~m}$ wide by $2-2.11 \mathrm{~m}$ high.

Orientation: east-west (entrance at east end).

While broadly similar to the Sardis decorative program, this tomb is distinguished by a different painting style, the absence of a delineated dado, and the inclusion of grape vines on the west wall

6579.2 and 79.3 were built into a hill in a stepped manner; the vault of 79.2 higher than that of 79.3 . Unpainted tomb 79.3 is 2.74-2.84 $\mathrm{m}$ long by 1.75-1.84 m wide and $1.75 \mathrm{~m}$ high (Erhart 1979, p. 1).

66 Paint primarily survives on the east and west walls, and the dado band runs $0.53-0.66 \mathrm{~m}$ from the floor. In the upper field of each of the east and west walls, a pheasant (?) nibbles at a basket of fruit with another bird (possibly a dove on the west and a robin on the east). The birds were painted with red, green, and red-brown with touches of white, yellow, and blue. The excavator described the vault as perhaps having been decorated with a trellis or arborway in addition to the strewn flowers, but photos suggest the usual garlands or wreaths (Erhart 1979, pp. 3-4).

67 The grave goods include a bronze buckle (M79.1:8417), terracotta bowl, and two 4th century coins (Greenewalt et al. 1983, p. 22).

68 Discovered in 1922, Shear published this tomb along with watercolors by Mrs. Shear (Shear 1922, pp. 405-7, Figures 13 and 14; Shear 1927, pp. 19-25, Figures 1-3, pls. III-VI); and also in (Hanfmann and Mierse 1983, p. 207, no. 2); WP 69.2. 
(Figure 18). ${ }^{69}$ On the east ends of each of the north and south walls, a peacock and a smaller bird (perhaps a peahen) face one another in near-mirror images. The east and west walls were delineated with a red band and a thinner green band, and two birds perch on the west wall's grape vines. All four walls were covered with multibloomed flowers and (on all but the west wall) quite regularly arranged garlands stiffly outlined and striped. ${ }^{70}$

Eleven complete lamps and fragments of others remained in the tomb. These may represent a single deposit, multiple visits or reuse but can only be broadly dated to the (late) Roman era. ${ }^{71}$ Based on style alone, Shear argued that the Kâgirlik Tepe tomb must be much earlier than the Painted tomb, which was the only Sardian comparandum available at the time (Shear 1927, p. 24). As noted above, I believe the opposite-that this is a later iteration of the Sardis painted tomb.

\section{Appendix A.8 T9. Tomb 79.1, Figures 23 and $24^{72}$}

Measurements: $3.22 \mathrm{~m}$ long by $2.30 \mathrm{~m}$ wide by $2.00 \mathrm{~m}$ high.

Orientation: east-west (entrance at east end).

While the basic elements of Tomb 79.1's decorative program are very similar to those of other Sardis hypogea, the style of painting is completely different. Wide red bands delineate a dado of five plain rectangles per wall. Above each dado is a three-swag garland with stylized baskets above and a very regular pattern of scattered flowers. The garlands and baskets were outlined with a compass in red with a red crisscross pattern with green dots in the lozenges and green v-shaped fringe. The symmetrically scattered "cotton blossom" flowers are pink and red with green leaves and stems. Yellow roundels with white spots are interspersed. ${ }^{73}$

Parallel bodies rested against the north and south walls with heads to the west. The matching deposition of the two bodies suggests that they were buried at the same time or at least within a generation. Gold earrings found with the south body indicate a female. The body to the north was buried with a gold diadem, clay lamp, clay bowl, and a coin of Valentinian II (375-92 C.E.). Another plain gold diadem was found in a heaped pile of earth in the northeast corner of the tomb (Greenewalt et al. 1983, pp. 24-25). Tomb 79.1 is the only unrobbed hypogeum discovered thus far at Sardis.

\section{Appendix A.9 T10. Artemis Precinct Tomb (Tomb AT.2), Figures 25 and $26^{74}$}

Measurements: $2.92 \mathrm{~m}$ long by $2.12 \mathrm{~m}$ wide by c. $1.85 \mathrm{~m}$ high.

Orientation: east-west (entrance at the east).

Tomb AT 2 is simply decorated in just red and black: A thick red band horizontally divides the curves of the lunettes and a dado area. In the upper zone, a thinner black band runs parallel to the red, with flourishes rather like inverted fleurs-de-lis with detached tips at the corners (between the black and red bands), in the lunettes. ${ }^{75}$ On the west lunette, just left of center, a bird perches on a branch and nibbles at the branch's red and black buds (Figure 25).

69 Only watercolor paintings recorded the decoration in this tomb at the time of its 1922 excavation, but a 2008 visit confirmed that the watercolors accurately captured its unusual painting style.

70 As Shear noted, these "garlands" seem to be open at the top and closed at the bottom and may well represent a bag stuffed with flowers, a carryover of Greek taenia, which also appears at Kertsch (Shear 1927, p. 21).

71 Shear dated the majority of the lamps to the first century C.E., with one "late or quasi-Christian", and argues that the range of dates indicates reuse of the tomb and an initial construction date no later than the second century. The current location of the lamps is unclear, and comparison via the drawing published by Shear does little to narrow chronology (Shear 1927, pp. 24-25, Figure 3).

72 Tomb 79.1, found between seasons, was excavated by the Manisa museum and published in (Greenewalt et al. 1983, pp. 22-25, Figures 27-30). Tomb 79.1 is also published as the "Tomb excavated by the Manisa Museum in 1979" in (Hanfmann and Mierse 1983, p. 208).

73 Garlands are 0.53-0.66 m across (Greenewalt et al. 1983, pp. 24-25).

74 This tomb was excavated by Butler, who reported that it contained no paintings (Butler 1922, p. 128), Majewski first catalogued the frescoes in 1969 as WP 69.1 and published a note on them in (Hanfmann 1970). The tomb is published in (Hanfmann and Mierse 1983, p. 207, no. 1) and in (Hanfmann and Waldbaum 1975, pp. 59-60, Figures 59, 61, 68, 72-74).

75 The corner flourishes are reminiscent of the domestic painting in MMS room 2 at Sardis. 
The presence of this tomb in the Artemis temple precinct is clear indication that it postdates sacred use of the temple and likely the construction of Church M in the east corner of the temple c. 400 (Buchwald 2015; Hanfmann and Mierse 1983, p. 195). ${ }^{76}$ Tomb AT 2 was under the northwest corner of Building $U$, a cella-and-pronaos building whose function and phases are unclear. Hanfmann and Waldbaum dated Building $U$ to the third-fourth century C.E and argued that it was built to deliberately incorporate the pre-existing tomb AT 2, though the walls are not in alignment. They dated the tomb to the first century C.E. date because of Hellenistic second century B.C.E. finds beneath the floor. ${ }^{77}$ Location and stylistic and compositional variation suggest that this tomb is earlier or later than the rest of the Sardis painted hypogea. Given the outstanding questions about Building U, and the location within the Artemis temple precinct, I am inclined to argue for a later, perhaps fifth century date.

\section{Appendix A.10 T11. Tomb under the House of the Bronzes (HoB), Unit $16^{78}$}

Measurements: $2.53 \mathrm{~m}$ long by $0.6 \mathrm{~m}$ wide by $1.00 \mathrm{~m}$ high.

Orientation: north-south.

This small vaulted tomb preserved under the floor of a sixth century Christian house was likely one of a number of graves found in this sector ranging in date from c. 200 C.E. or earlier into the fourth-fifth century. ${ }^{79}$ The HoB sector included an extramural cemetery precinct prior to its incorporation within the city walls with c. 400 C.E. construction of the city wall extension that also incorporated the synagogue and Bath-Gymnasium complex. The only records of the tomb decoration include a description likening it to the Kâgirlik Tepe tomb and a very cursory sketch of wreaths and scattered flowers in the conservation record. The drawing shows a red wreath surrounded by twelve roses on a short wall and a red wreath and some roses on one long wall and similar traces on the other long wall. ${ }^{80}$ This is at least sufficient evidence to place the HoB tomb comfortably within the Sardis type. Only its much smaller size sets it apart.

\section{Appendix A.11 T12. Pactolus Cliff (LVC and SVC) ${ }^{81}$}

Measurements:

LVC: $3.85 \mathrm{~m}$ long by $3.15 \mathrm{~m}$ wide by c. $2.00 \mathrm{~m}$ high.

SVC: $2.5 \mathrm{~m}$ long by $1.8 \mathrm{~m}$ wide, unknown height.

Construction materials: brick and concrete of mortared rubble and stone slab floors.

Orientation: one is north-south and one is east-west.

The large vaulted chamber (LVC) and small vaulted chamber (SVC) comprised a tomb complex with multiple burials beneath stone floor slabs. ${ }^{82}$ No visual record of the tomb decoration remains,

76 In addition, Butler excavated four vaulted and perhaps plastered tombs on the south side of the Artemis temple, which can only be tentatively dated as "early Byzantine" due to their poor state of preservation (Hanfmann and Waldbaum 1975, pp. 60, 66-67, Figures 59, 98-100; Butler 1922, p. III).

77 (Hanfmann and Waldbaum 1975, pp. 56, 58-61, Figures 59, 61, 68). See also (Hanfmann and Mierse 1983, pp. 195, 205).

78 This tomb was excavated in 1959 (Hanfmann 1960, p. 26; Hanfmann and Mierse 1983, p. 208, no. 5).

79 A coin of Justin II (565-578 C.E.) sealed between the tomb and floor of the house above gives a broad terminus ante quem, but there is every reason to date the tomb to the fourth century (Mitten 1980, pp. 8-13).

80 The 1967 Sardis conservation lab record states that little painting remained, but it was faced with muslin and cleaned in July 1964. No remains or images have survived.

81 In 1959, a landslide exposed remains in the Pactolus cliff, which proved to be from multiple periods (Hanfmann 1960, pp. 14-16, Figures 3 and 4). Both chambers were removed during the 1960 season in order to reach the Lydian levels below (Del Chiaro 1960, p. 1).

82 The two spaces were connected with their vaults at right angles to one another: A door in the north wall of LVC led into SVC, and it appears that LVC was oriented east-west and SVC north-south. The stone slabs making up the floor of each chamber covered burial pits built of stuccoed tiles (five in LVC and two in SVC). Pit 1 in LVC contained the sculpted head of a priest dated to the second half of the third century C.E. Hanfmann notes that the pits had already been opened but still contained glass and pottery (upon which he does not elaborate) (Hanfmann 1960, pp. 14-16, Figures 3 and 4 ). 
but Hanfmann likened the painted scattered flowers still visible on the north and west walls of SVC to the Painted Tomb. ${ }^{83}$

\section{References}

Alexander, Catherine Swift. 2008. 2008 Drafting Report, Unpublished report. Archaeological Exploration of Sardis. Alföldi-Rosenbaum, Elisabeth. 1971. Anamur Nekropolü. The Necropolis of Anemurium. Ankara: Türk Tarih Kurumu Basımevi.

Barbet, Alix. 2005. Zeugma II. Peintures Murales Romaines. Istanbul: Institut français D'études Anatoliennes-Georges Dumézil.

Barbet, Alix. 2007. Le chrisme dans la peinture murale romaine. In Konstantin der Grosse: Geschichte, Archäologie, Rezeption; internationales Kolloquium vom 10-15 Oktober 2005 an der Universität Trier zur Landesausstellung Rheinland-Pfalz. Edited by Alexander Demandt and Josef Engemann. Trier: Rheinisches Landesmuseum, pp. 127-41.

Barbet, Alix. 2014. Le Semis de Fleurs en Peinture Murale entre Mode et Style? In Actes du XIe Colloqie de l'Association Internationale pour la Peinture Murale Antique (Ephesos 13-17 September, 2010). Edited by Norbert Zimmermann. Vienna: Österreichischen Akademie der Wissenschaften, pp. 199-207.

Barbet, Alix, and Claude Vibert-Guigue. 1994. Les Peintures des Nécropoles Romaines D'Abila Et Du Nord De La Jordanie. Beyrouth: Institut Français d'Archéologie du Proche-Orient.

Barbet, Alix, Pierre-Louis Gatier, and Norman N. Lewis. 1997. Un tombeau peint inscrit de Sidon. Syria 74: 141-60.

Bisconti, Fabrizio. 2002. The Decoration of the Roman Catacombs. In The Christian Catacombs of Rome. Edited by Vincenzo Fiocchi Nicolai, Fabrizio Bisconti and Danilo Mazzoleni. Translated by Cristina Carlo Stella, and Lori-Ann Touchette. Regensburg: Schnell \& Steiner, pp. 71-145.

Borg, Barbara. 2013. Crisis and Ambition: Tombs and Burial Customs in Third-Century CE Rome. Oxford: Oxford University Press.

Buchwald, Hans. 2015. Churches EA and Eat Sardis. Archaeological Exploration of Sardis, Report 6. Cambridge: Archaeological Exploration of Sardis.

Butler, Howard Crosby. 1913. Fourth Preliminary Report on the American Excavations at Sardes in Asia Minor. American Journal of Archaeology 17: 471-78. [CrossRef]

Butler, Howard Crosby. 1922. Sardis, The Excavations Part I, 1910-1914. Leiden: Brill.

Calza, Guido. 1940. La necropoli del Porto di Roma nell' Isola Sacra. Roma: La Libreria Dello Stato.

Carroll, Maureen. 2006. Spirits of the Dead: Roman Funerary Commemoration in Western Europe. Oxford: Oxford University Press.

Clarke, John R. 1991. The Houses of Roman Italy, 100 B.C.-A.D. 250: Ritual, Space, and Decoration. Berkeley: University of California Press.

Clarke, John R. 2003. Art in the Lives of Ordinary Romans: Visual Representation and Non-Elite Viewers in Italy, 100 B.C.-A.D. 315. Berkeley: University of California Press.

Connerton, Paul. 1989. How Societies Remember. Cambridge: Cambridge University Press.

Cormack, Sarah. 1997. Funerary Monuments and Mortuary Practice in Roman Asia Minor. In The Early Roman Empire in the East. Edited by Susan Alcock. Oxford: Oxbow Monograph 95, pp. 137-56.

Cumont, Franz Valery Marie. 1942. Recherches sur le Symbolisme Funéraire des Romains. Paris: P. Geuthner.

D'Angelo, Tiziana. 2008. Tomb 07.2 and Tomb 07.3 Mid-Season Report. Unpublished report, Archaeological Exploration of Sardis.

Davies, Douglas James. 2002. Death, Ritual and Belief: The Rhetoric of Funerary Rites. New York: Continuum.

Del Chiaro, Maria A. 1960. Pactolus Cliff Excavations, 1960. Unpublished Report, Archaeological Exploration of Sardis.

Deleman, İnci. 2008. Perge'den bir Yemek Sahnesinde Batı Yankıları. In Festschrift für Prof. Dr. Haluk Abbasoğlu zum 65. Haluk Abbasoğlu zum 65 Geburtstag. Edited by İnci Deleman, Sedef Çokay-Kepçe, Aşkım Özdizbay and Özgür Turak. İstanbul: AKMED, vol. 1, pp. 371-81.

83 According to the 1960 final report, SVC and LVC were removed in order to reach earlier levels (Del Chiaro 1960, p. 1). 
Denzey Lewis, Nicola. 2013. Roses and Violets for the Ancestors Gifts to the Dead and Ancient Roman Forms of Social Exchange. In The Gift in Antiquity. The Ancient World. Comparative Histories. Edited by Michael L. Satlow. Chichester: Wiley-Blackwell, pp. 122-36.

Denzey Lewis, Nicola. 2016. Memory in Late Roman Mortuary Spaces. In Memory in Ancient Rome and Early Christianity. Edited by Karl Galinsky. Oxford: Oxford University Press, pp. 263-85.

Dunbabin, Katherine M. D. 1978. The Mosaics of Roman North Africa: Studies in Iconography and Patronage. New York: Oxford University Press.

Elsner, Jaś. 1995. Art and the Roman Viewer: The Transformation of Art from the Pagan World to Christianity. New York: Cambridge University Press.

Elsner, Jaś. 2007. Roman Eyes: Visuality and Subjectivity in Art and Text. Princeton: Princeton University Press.

Erhart, Katherine Patricia. 1979. Tombs 79-2 and 79-3 Final Report. Unpublished report, Archaeological Exploration of Sardis.

Feraudi-Gruénais, Francisca. 2015. The Decoration of Roman Tombs. In A Companion to Roman Art. Edited by Barbara E. Borg. Chichester: Wiley Blackwell, pp. 429-51.

Foss, Clive. 1976. Byzantine and Turkish Sardis. Cambridge: Harvard University Press.

Foss, Clive. 1979. The Fabricenses Ducenarii of Sardis. Zeitschrtfifiir Papyrologie und Epigraphik 35: $279-83$.

Gadbery, Laura. 1993. Roman wall-painting at Corinth: new evidence from east of the Theater. In The Corinthia in the Roman Period: Including the Papers Given at a Symposium Held at The Ohio State University on 7-9 March, 1991. Edited by Timothy E. Gregory. Ann Arbor: Journal of Roman Archaeology, pp. 47-64.

Gee, Regina. Forthcoming. Funerary Imagery and Iconography. In Oxford Handbook of Imagery and Iconography. Edited by Lea Cline and Nathan Elkins. Oxford: Oxford University Press.

Goodenough, Erwin R. 1965. Jewish Symbols in the Greco-Roman Period. New York: Pantheon Books.

Grabar, Oleg. 1992. The Mediation of Ornament. Princeton: Princeton University Press.

Greenewalt, Crawford H., Jr. 1977. The Twentieth campaign at Sardis 1977. Rivista di Archeologia 2: 105-8.

Greenewalt, Crawford H., Jr. 1978. The Sardis Campaign of 1976. Bulletin of the American Schools of Oriental Research 229: 58-73. [CrossRef]

Greenewalt, Crawford H., Jr. 1979. The Sardis Campaign of 1977. Bulletin of the American Schools of Oriental Research 233: 1-32. [CrossRef]

Greenewalt, Crawford H., Jr., and Machteld J. Mellink. 1977. Archaeology in Asia Minor. American Journal of Archaeology 81: 308-10.

Greenewalt, Crawford H., Jr., Andrew Ramage, Donald G. Sullivan, Kubilây Nayir, and Atilla Tulga. 1983. The Sardis Campaigns of 1979 and 1980. Bulletin of the American Schools of Oriental Research 249: 3-44. [CrossRef]

Greenewalt, Crawford H., Jr., Christopher Ratté, and Marcus L. Rautman. 1995. The Sardis Campaigns of 1992 and 1993. Annual of the American Schools of Oriental Research 52: 1-36.

Hanfmann, George M. A. 1952. The Season Sarcophagus in Dumbarton Oaks. 2 vols. London: Oxford University Press.

Hanfmann, George M. A. 1960. Excavations at Sardis, 1959. Bulletin of the American Schools of Oriental Research 157: 8-43. [CrossRef]

Hanfmann, George M. A. 1962. The Fourth Campaign at Sardis (1961). Bulletin of the American Schools of Oriental Research 166: 1-57. [CrossRef]

Hanfmann, George M. A. 1970. The Eleventh and Twelfth Campaigns at Sardis $(1968,1969)$. Bulletin of the American Schools of Oriental Research 199: 7-58. [CrossRef]

Hanfmann, George M. A. 1972. Letters from Sardis. Cambridge: Harvard University Press.

Hanfmann, George M. A. 1981. A Painter in the Imperial Arms Factory at Sardis. American Journal of Archaeology 85: 87-88. [CrossRef]

Hanfmann, George M. A., and W. E. Mierse. 1983. Sardis From Prehistoric to Roman Times: Results of the Archaeological Exploration of Sardis 1958-1975. Cambridge: Harvard University Press.

Hanfmann, George M. A., and Jane C. Waldbaum. 1975. A Survey of Sardis and the Major Monuments Outside the City. Sardis R1. Cambridge: Harvard University Press.

Hansen, Donald P. n.d. Peacock Tomb. Unpublished report, Archaeological Exploration of Sardis.

Hemans, Caroline Jane. 1987. Late Antique Painting from Stobi, Yugoslavia. Ph.D. dissertation, Indiana University, Bloomington, IN, USA. 
Hölscher, Tonio. 2004. The Language of Images in Roman Art. Translated by Anthony Snodgrass, and Annemarie Künzl-Snodgrass. with a Foreword by Jaś Elsner. Cambridge: Cambridge University Press.

Johnson, Mark Joseph. 1999. Pagan-Christian Burial Practices of the Fourth Century: Shared Tombs? In Christianity and Society: The Social World of Early Christianity. Edited by Everett Ferguson. New York: Garland Publishing Inc., pp. 385-407.

Jones, Richard. 1987. Burial Customs of Rome and the Provinces. In The Roman World. Edited by John Wacher. New York: Routledge \& Kegan Paul, pp. 812-37.

Kay, N. M. 2015. Ausonius: Epigrams. London: Bloomsbury Publishing.

Kennedy, David, and Julie Kennedy. 1998. The Twin Towns and the Region. In The Twin Towns of Zeugma on the Euphrates: Rescue Work and Historical Studies. Edited by David Kennedy. Portsmouth: Journal of Roman Archaeology, pp. 30-59.

Maguire, Henry. 1987. Earth and Ocean: The Terrestrial World in Early Byzantine Art. University Park: State University Press.

Maguire, Henry. 1990. Garments Pleasing to God: The Significance of Domestic Textile Designs in the Early Byzantine Period. Dumbarton Oaks Papers 44: 215-24. [CrossRef]

Maguire, Eunice Dauterman, Henry Maguire, and Maggie J. Duncan-Flowers. 1989. Art and Holy Powers in the Early Christian Church. Urbana: University of Illinois Press.

Majewski, Lawrence J. 1970. Report on the Present Status of The Sardis Mosaic and Wall Painting: Activities and Other Work from June 28 to August 1. Unpublished report, Archaeological Exploration of Sardis.

Majewski, Lawrence J. 1973. Report on the Study of Wall Paintings and Mosaics at Sardis: August 1 to September 21. Unpublished report, Archaeological Exploration of Sardis.

Majewski, Lawrence J. 1977. Report on the Conservation and Technical Study of the Wall Painting in the Tomb of Chrysanthios-Tomb 76.1, July 1-August 9. Unpublished report, Archaeological Exploration of Sardis.

Mellink, Machteld J. 1977. Archaeology in Asia Minor. American Journal of Archaeology 81: 289-321. [CrossRef]

Michaeli, Talila. 2004. The Pictorial Program of the Tomb near Kibbutz Or-ha-Ner in Israel. In Plafonds et Voûtes à L'époque Antique. Actes du VIIIe Colloque International de l'Association Internationale pour la Peinture Murale Antique (AIPMA) 15-19 mai 2001, Budapest-Veszprém. Edited by Borhy L. avec la collaboration de Sylvia Palágyi et de Myrtill Magyar. Budapest: Pytheas Publishing, pp. 37-76.

Mitten, David Gordon. 1980. House of Bronzes 1980: Final Report. Unpublished report, Archaeological Exploration of Sardis.

Noy, David. 2004. Where were the Jews of the Diaspora buried? In Jews in a Graeco-Roman World. Edited by Martin Goodman. Oxford: Oxford University Press, pp. 75-90.

Pencheva, Angela. 2017. An Interpretation of the 'Wreath' in the Context of the Hellenistic Macedonian and Thracian Funerary Mural Painting. In Actes du XIIe Colloqie de l'Association Internationale Pour la Peinture Murale Antique (Athens 16-20 September, 2013). Edited by Eric Moormann. Leuven: Babesch, pp. 179-84.

Platt, Verity. 2012. Framing the Dead on Roman Sarcophagi. RES: Anthropology and Aesthetics 61: 213-27. [CrossRef]

Rautman, Marcus. 2011. Sardis in Late Antiquity. In Archaeology and the Cities of Asia Minor in Late Antiquity. Edited by Ortwin Dally and Christopher Ratté. Ann Arbor: Kelsey Museum of Archaeology, University of Michigan.

Rostovtzeff, Michael Ivanovitch. 1919. Ancient Decorative Wall-Painting. Journal of Hellenic Studies 39: 144-63. [CrossRef]

Rostovtzeff, Michael Ivanovitch. 2004. La Peinture Décorative Antique En Russie Méridionale: Saint-Pétersbourg 1913-1914. Volume 1: Texte, Description Et Étude Des Documents. Volume 2: 112 Planches. Mémoires De L'académie des Inscriptions Et Belles-Lettres, Xxviii. Paris: Académie Des Inscriptions Et Belles-lettres.

Rousseau, Vanessa. 2010. Late Roman Wall Painting at Sardis. Ph.D. dissertation, University of Wisconsin, Madison, WI, USA.

Rousseau, Vanessa. 2014. Paradisiacal Tombs and Architectural Rooms In Late Roman Sardis: Period Styles And Regional Variants. In Actes du XIe Colloqie de l'Association Internationale pour la Peinture Murale Antique. (Ephesos 13-17 September, 2010). Edited by Norbert Zimmermann. Vienna: Österreichischen Akademie der Wissenschaften, pp. 193-98.

Rozenberg, Silvia. 1996. The wall paintings of the Herodian Palace at Jericho. In Judaea and the Greco-Roman World in the time of Herod in the Light of Archaeological Evidence: Acts of a Symposium Organized by the Institute of Archaeology, The Hebrew University of Jerusalem and the Archaeological Institute, Georg-August-University of 
Göttingen at Jerusalem, November 3rd-4th 1988. Edited by Klause Fittschen and Gideon Foerster. Göttingen: Vandenhoeck \& Ruprecht, pp. 121-38.

Scheller, Robert Walter Hans Peter. 1995. Exemplum: Model-Book Drawings and the Practice of Artistic Transmission in the Middle Ages (ca. 900-ca. 1470). Translated by Michael Hoyle. Amsterdam: Amsterdam University Press.

Schmidt-Colinet, Andreas. 1996. East and West in Palmyrene Pattern Books. In Palmyra and the Silk Road: International Colloquium, Palmyra, 7-11 Avril 1992. Damascus: Directorate-General of Antiquities and Museums, pp. 417-23.

Shear, Theodore Leslie. 1922. Sixth Preliminary Report on the American Excavations at Sardes in Asia Minor. American Journal of Archaeology 26: 389-409. [CrossRef]

Shear, Theodore Leslie. 1927. A Roman Chamber-Tomb at Sardis. American Journal of Archaeology 31: 19-25. [CrossRef]

Thébert, Yvon. 1987. Private Life and Domestic Architecture in Roman Africa. In A History of Private Life I. from Pagan Rome to Byzantium. Edited by Paul Veyne. Cambridge: The Belknap Press of Harvard University Press, pp. 313-410.

Toynbee, Jocelyn M. C. 1971. Death and Burial in the Roman World. Ithaca: Cornell University Press.

Toynbee, Jocelyn M. C. 1973. Animals in Roman Life and Art. Ithaca: Cornell University Press.

Valeva, Julia. 1980. Sur certaines particularités des hypogées paléochrétiens des terres thraces et leurs analogue en Asie Mineure. Anatolica 7: 117-50.

Volp, Ulrich. 2002. Tod Und Ritual in Den Christlichen Gemeinden der Antike. Leiden: Brill.

Von Hesberg, Henner, Christiane Nowak, and Ellen Thiermann. 2015. Religion and Tomb. In A Companion to the Archaeology of Religion in the Ancient World. Edited by Rubina Raja and Rüpke Jörg. Hoboken: Wiley Blackwell, pp. 235-49.

Williams, M. 1994. The Organisation of Jewish Burials in Ancient Rome in the Light of Evidence from Palestine and the Diaspora. Zeitschrift Für Papyrologie Und Epigraphik 101: 165-82.

Zimmermann, Norbert. 2015. Catacombs and the Beginnings of Christian Tomb Decoration. In A Companion to Roman Art. Edited by Barbara E. Borg. Chichester: Wiley Blackwell, pp. 452-70.

Zimmermann, Norbert, Sabine Ladstätter, and Mustafa Büyükkolanc1. 2011. Wall Painting in Ephesos from the Hellenistic to the Byzantine Period. Istanbul: Ege Yayınları.

(C) 2019 by the author. Licensee MDPI, Basel, Switzerland. This article is an open access article distributed under the terms and conditions of the Creative Commons Attribution (CC BY) license (http://creativecommons.org/licenses/by/4.0/). 